\title{
Geology and petrogenetic considerations of the Loma Marcelo skarn, Neoproterozoic basement of the Ventania System, Argentina
}

\author{
Carlos A. Ballivián Justiniano ${ }^{\mathrm{a}, \mathrm{f}}$, Mabel E. Lanfranchini ${ }^{\mathrm{a}, \mathrm{g}, *}$, Clemente Recio ${ }^{\mathrm{b}}$, Raúl E. de Barrio ${ }^{\mathrm{a}}$, \\ Ana María Sato ${ }^{\mathrm{c}, \mathrm{f}}$, Miguel A.S. Basei ${ }^{\mathrm{d}}$, Marcio M. Pimentel ${ }^{\mathrm{e}}$, Ricardo O. Etcheverry ${ }^{\mathrm{a}, \mathrm{f}}$, \\ Colombo C.G. Tassinari ${ }^{\mathrm{d}}$ \\ ${ }^{a}$ Instituto de Recursos Minerales (INREMI), Universidad Nacional de La Plata-CIC, Calle 64 esquina 120, 1er piso, C.P. 1900 La Plata, Argentina \\ b Departamento de Geología, Facultad de Ciencias, Universidad de Salamanca, Plaza de los Caídos $s / n$, 37008 Salamanca, Spain \\ ' Centro de Investigaciones Geológicas (CIG), CONICET-Universidad Nacional de La Plata, Diagonal 113 N²75, C.P. B1904DPK La Plata, Argentina \\ d Centro de Pesquisas Geocronológicas (CPGeo), Instituto de Geociências, Universidade de São Paulo, Cidade Universitária, Rua do Lago 562, CEP 05508-080 São Paulo, \\ SP, Brazil \\ e Laboratório de Geocronologia, Instituto de Geociências, Universidade de Brasília, Campus Universitário Darcy Ribeiro, Asa Norte, CEP 70910-900 Brasília, DF, Brazil \\ ${ }^{\mathrm{f}}$ Consejo Nacional de Investigaciones Científicas y Técnicas (CONICET), Argentina \\ ${ }^{g}$ Comisión de Investigaciones Científicas de la Provincia de Buenos Aires (CIC), Argentina
}

\section{A R T I C L E I N F O}

\section{Keywords:}

Geochemistry

Geochronology

Carbonate protoliths

Polymetamorphism

Sierras Australes of Buenos Aires Province

\begin{abstract}
A B S T R A C T
The Late Precambrian-Early Palaeozoic crystalline basement of the Ventania System is mainly composed of Neoproterozoic S-type granites, Early Cambrian alkaline granites, and Middle Cambrian peralkaline rhyolites. The Neoproterozoic granites ( $c a$. 607-581 Ma) crop out in the Cerro Pan de Azúcar-Cerro del Corral area and host the Loma Marcelo $\mathrm{Ca} / \mathrm{Mg}$ skarn, composed of calc-silicate- and chondrodite-bearing assemblages. Petrographical, geochemical, and geochronological data indicate that the skarn was formed from carbonate xenoliths of sedimentary nature incorporated during the intrusion of the Neoproterozoic granites and that it is the result of three successive metamorphic events. The first one is related to the incorporation of carbonate xenoliths by the intrusion and the associated contact metamorphism. The second event is linked to the crystallization of the Early Cambrian granites and related post-magmatic processes. They are responsible for fluorine influx into the Neoproterozoic basement, which resulted in the formation of high-F minerals in the Loma Marcelo skarn (e.g. vesuvianite, chondrodite). The Sm-Nd garnet-whole rock isochron age of $526.8 \pm 12.0 \mathrm{Ma}$ in the skarn confirms its relationship with the Early Cambrian magmatism. The last event corresponds to a regional metamorphism assigned to the Late Devonian-Early Carboniferous on the basis of a LA-ICP-MS U-Pb age of $353.4 \pm 6.7 \mathrm{Ma}$ determined on zircons of the skarn as well as a Rb-Sr quartz-sericite isochron age of $364.4 \pm 3.6 \mathrm{Ma}$ obtained from a quartz vein that post-tectonically cuts the already mylonitized granites. The different chemical compositions of the carbonate protoliths determined the formation of two types of skarns of calcic and magnesian compositions. A single date of the calcic skarn defined a LA-ICP-MS U-Pb upper intercept age of $648 \pm 21 \mathrm{Ma}$, providing the maximum sedimentation age for the calcic protolith of the Loma Marcelo skarn. The minimum sedimentation age is provided by the crystallization age of the S-type granite surrounding the skarn (ca. $607 \mathrm{Ma}$ ). The Loma Marcelo skarn reveals the occurrence of underground Neoproterozoic carbonate (meta-?) sedimentary rocks as part of the basement of the Ventania System. These rocks could correlate with the carbonate sequences of the neighbouring Claromecó Basin and Tandilia System.
\end{abstract}

\section{Introduction}

The Ventania System, or Sierras Australes of Buenos Aires Province, is located at the southeastern end of the South American Platform defined by de Almeida (1971) (Fig. 1a) in the southeastern part of the Buenos Aires Province, Argentina (Fig. 1b). It constitutes part of the
"Bonaerense Positive" (Yrigoyen, 1975) along with the adjacent Claromecó Basin and the Tandilia System or Sierras Septentrionales of Buenos Aires Province (Fig. 1c). The Ventania System is mainly composed of Palaeozoic siliciclastic sedimentary rocks (Fig. 2), which were significant elements in the reconstruction of West Gondwana, and is considered as the conjugate margin of the Cape Fold Belt in South

\footnotetext{
* Corresponding author at: Instituto de Recursos Minerales (INREMI), Universidad Nacional de La Plata-CIC, Calle 64 esquina 120, $1 \mathrm{er}$ piso, C.P. 1900 La Plata, Argentina.

E-mail address: lanfranchini@yahoo.com (M.E. Lanfranchini).
} 


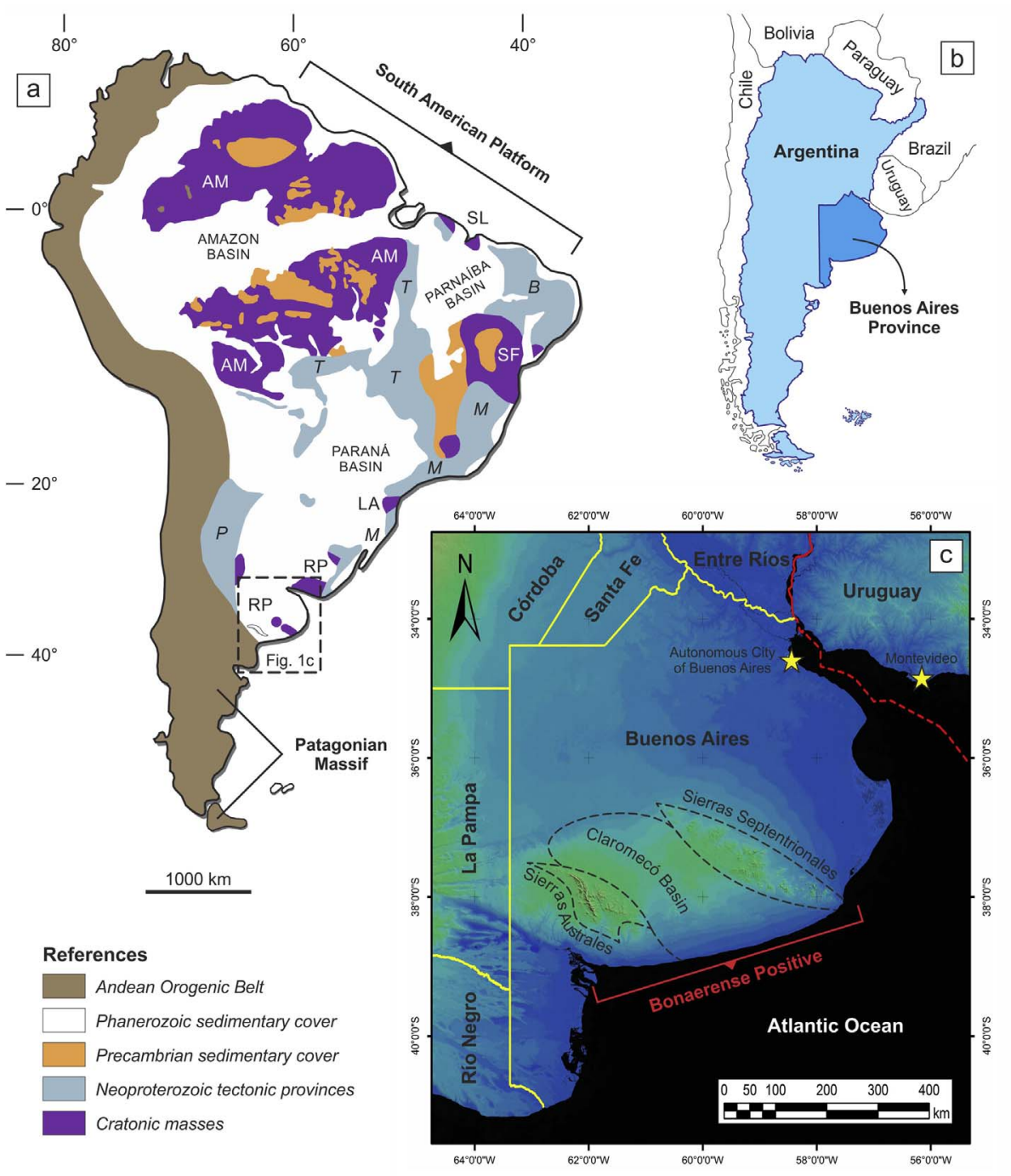

Fig. 1. a) Geological map of South America with emphasis on the South American Platform (modified from Basei et al. (2010)). b) Political map of Argentina, indicating the Buenos Aires Province. c) LANDSAT satellite image of the Buenos Aires Province, indicating the morphostructural units that make up the Bonaerense Positive. Cratons: $\mathrm{AM}=$ Amazonian, $\mathrm{SL}=$ São Luís, $\mathrm{SF}=$ São Francisco, LA $=$ Luiz Alves, $R P=$ Río de la Plata. Neoproterozoic tectonic provinces: $\mathrm{B}=$ Borborema, $\mathrm{T}=$ Tocantins, $\mathrm{M}=$ Mantiqueira, $\mathrm{P}=$ Pampean
Africa (Keidel, 1916; Du Toit, 1927). The crystalline basement of the Ventania System, which has a Neoproterozoic-Middle Cambrian age (Rapela et al., 2003; Tohver et al., 2012), crops out in different sectors along the western side of the system. It consists of granites, rhyolites, ignimbrites, and small bodies of andesitic, calc-silicate, and metacarbonate rocks (Fig. 2). K-Ar, Rb-Sr (Cingolani and Varela, 1973; Varela and Cingolani, 1976), and SHRIMP U-Pb (Rapela et al., 2003; Tohver et al., 2012) dating of the basement rocks from the Ventania System made it possible to assign the genesis of these rocks to the magmatic activity of the Brasiliano Orogenic Cycle.

The crystalline basement of the Ventania System is mainly composed of Neoproterozoic granites, Early Cambrian granites, and Middle Cambrian rhyolites. The Neoproterozoic basement crops out in the Cerro Pan de Azúcar-Cerro del Corral area (Fig. 2), one of the most deformed zones of the system. In this area, the basement units are lithologically diverse and involve a considerable structural complexity. They consist mainly of S-type granites and minor phenodacitic to phenorhyolitic rocks, a dyke-like andesitic body, and the Loma Marcelo skarn. The granites seem to be the continuity of the magmatism associated with the Dom Feliciano Belt of Brazil and Uruguay or alternatively with that of the Saldania Belt of South Africa (Rapela et al., 2003). Chemale et al. (2011) concluded that the correlation between the Dom Feliciano and Saldania belts is not direct due to the existence of geochronological and isotopic differences. The skarn consists of small bodies of calc-silicate and metacarbonate rocks spatially linked to the Neoproterozoic S-type granites.

Kilmurray (1968) defined the calc-silicate rocks from Loma Marcelo as skarn. He later indicated that calc-silicate and magnesian associations comprising the skarn were the result of metasomatism of calcareous relicts of the crystalline basement (Kilmurray, 1975). In agreement with Kilmurray $(1968,1975)$, Ballivián Justiniano et al. (2015) indicated that the Loma Marcelo skarn would be an indirect evidence of carbonate rocks at depth and additionally reported the occurrence of mineral associations corresponding to at least two overlapped metasomatic events.

The aim of this paper is to present new geochemical and geochronological data in order to propose the petrogenetic evolution of the Loma Marcelo skarn and to discuss the origin of the carbonate protoliths.

The geochemical results presented here allow the sedimentary nature of the carbonate protoliths of the skarn and the existence of at least three metamorphic events registered in the skarn to be established. New geochronological data allow one of these metamorphic events to be linked to the hydrothermal activity related to the Early Cambrian magmatism of the Ventania System. They also reveal the existence of a tectonometamorphic event of Late Devonian-Early Carboniferous age.

The results of this research are considered relevant at local and 


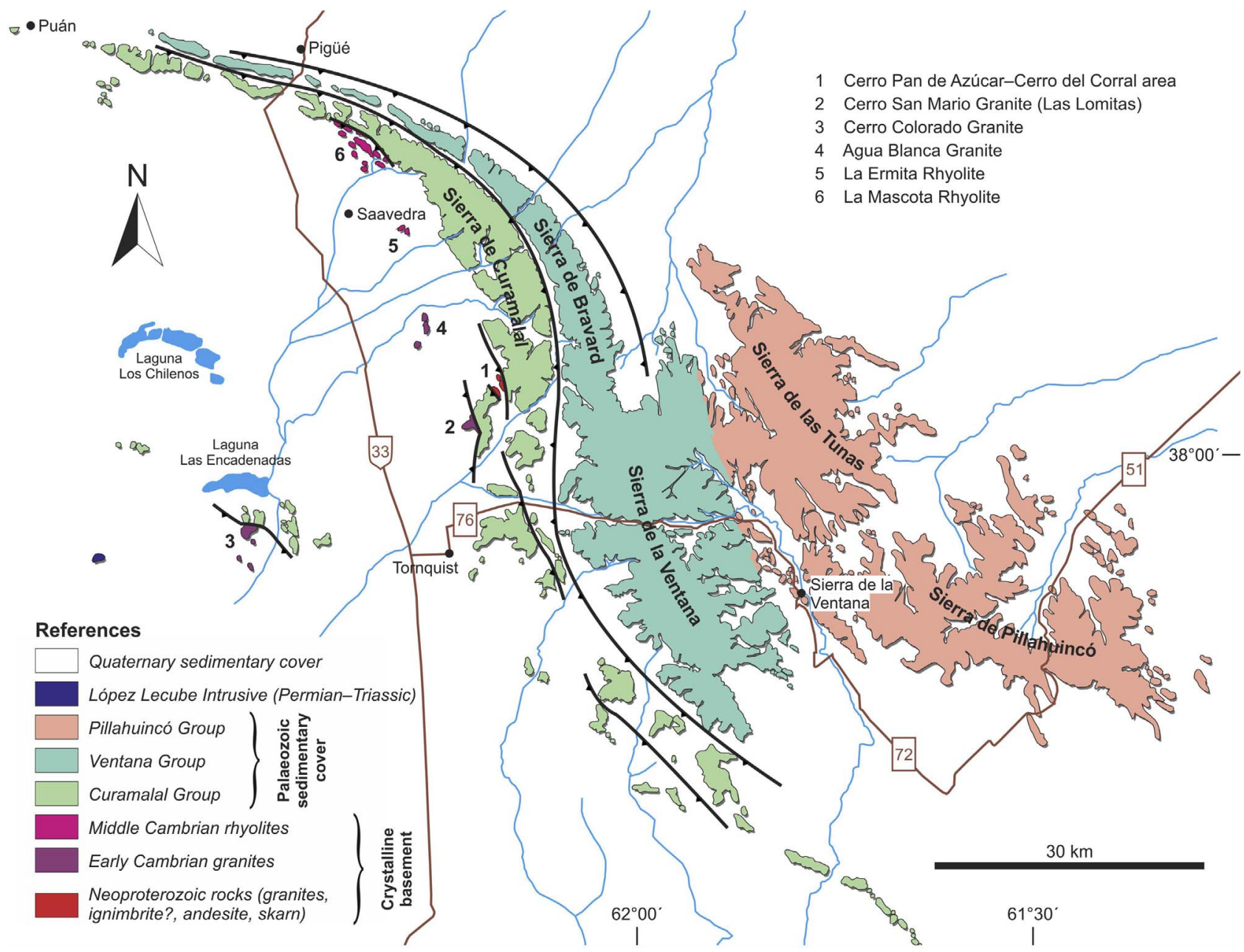

Fig. 2. Geological map of the Ventania System (modified from Ramos et al. (2014)).

regional scales since they contribute to the knowledge of the rocks present in the underground of the Ventania System. Specially, the skarn protoliths evidence their relation with the Neoproterozoic carbonate sedimentation of Southwest Gondwana.

\section{Regional geologic setting}

The Ventania System crystalline basement crops out along the western edge of the Sierra de Curamalal and in the adjacent plain that extends to the west (Fig. 2). It consists of granites at Cerro Pan de Azúcar, Cerro del Corral, Cerro San Mario, Cerro Colorado, and Estancia Agua Blanca; rhyolites at Cerro La Ermita and Estancia La Mascota; ignimbrites at Cerro del Corral; an andesite at Cerro Pan de Azúcar, and calc-silicate and metacarbonate rocks at Loma Marcelo. All of these rocks are deformed to different extents and are cut by post-tectonic quartz veins and veinlets.

Cingolani and Varela (1973) and Varela and Cingolani (1976) performed the first $\mathrm{K}-\mathrm{Ar}$ and $\mathrm{Rb}-\mathrm{Sr}$ systematic dating of the Ventania System basement rocks. The ages obtained spanned from the Cryogenian to the Late Triassic. The post-Cambrian ages obtained in the basement rocks would be the result of partial or total opening of the $\mathrm{K}-\mathrm{Ar}$ and $\mathrm{Rb}-\mathrm{Sr}$ isotopic systems caused by the Neopalaeozoic deformation and its related warming and fluid circulation (von Gosen et al., 1990). In this sense, former $\mathrm{K}-\mathrm{Ar}$ and $\mathrm{Rb}-\mathrm{Sr}$ ages are interpreted as minimum ages.

Petrological and SHRIMP U-Pb zircon data (Rapela et al., 2003; Gregori et al., 2005; Tohver et al., 2012) allow three stages of magmatic activity to be distinguished in the basement:
1) The first stage, of Ediacaran age ( $c a .607-581 \mathrm{Ma}$ ), is represented by the S-type granites of the Cerro Pan de Azúcar-Cerro del Corral area. It is related to the collisional orogeny responsible for the closure of the Adamastor Ocean (Hartnady et al., 1985), a restricted ocean located between South America and Africa. Its closure was linked to the assembly of West Gondwana (Cordani et al., 2013).

2) The second stage corresponds to a magmatic event of Early Cambrian age (ca. 533-524 Ma), which is associated with the collapse of the Neoproterozoic collisional orogen. It is represented by the alkaline granites of Cerro Colorado and Estancia Agua Blanca and by the calc-alkaline granite of Cerro San Mario (Fig. 2).

3) The third stage, of Middle Cambrian age ( $c a$. 509-505 Ma), is represented by the peralkaline rhyolites of Cerro La Ermita and Estancia La Mascota (Fig. 2), which are associated with the emplacement of a thermal anomaly (mantle plume or mafic underplate).

The sedimentary cover of the Ventania System comprises three sedimentary units (Harrington, 1947): Curamalal (Late Cambrian-Ordovician), Ventana (Silurian-Devonian), and Pillahuincó (Carboniferous-Permian) groups (Fig. 2). The Curamalal and Ventana groups represent stable platform sedimentary sequences (Andreis et al., 1989) mainly composed of quartzites and sandstones with minor basal conglomerates and cuspidal pelites. Although some authors proposed that the Curamalal and Ventana groups may be the same tectonically repeated unit (Kilmurray, 1975; Tomezzoli and Cristallini, 2004), there is currently general agreement regarding the validity of the original scheme proposed by Harrington (1947), which 
considered them as two separate units. The sedimentary rocks of the Pillahuincó Group crop out in Sierra de las Tunas and Sierra de Pillahuincó, along the eastern sector of the Ventania System. In addition, they extend towards the underground between the Ventania and Tandilia systems, where they are part of the infilling of the Claromecó Basin. The main rock types that comprise the Pillahuincó Group are diamictites, conglomerates, quartzites, arkoses, and dark grey pelites of glacimarine and fluvio-deltaic environments (Andreis et al., 1989) and minor intercalations of tuff horizons (Iñíguez et al., 1988). Geophysical and drilling data allowed the offshore continuity of at least part of the sedimentary sequence to be identified (Pángaro and Ramos, 2012; Pángaro et al., 2016). There is no evidence of igneous activity affecting the Palaeozoic sedimentary sequence of the Ventania System.

On the basis of detrital zircon provenance studies, the most likely source areas of the Curamalal and Ventana groups are Tandilia System and Sierras Pampeanas of central-west Argentina (Uriz et al., 2011; Ramos et al., 2014). The main source of the Pillahuincó Group was the magmatic arc proposed by Ramos (2008) for Northern Patagonia along the Somún Curá Massif. Ramos et al. (2014) also proposed the same magmatic arc as the source of the pyroclastic materials interbedded in the upper section of the Pillahuincó Group.

Both the crystalline basement (mylonitized) and the Palaeozoic sedimentary cover (folded and faulted) are deformed. The conspicuous structural feature of the Ventania System is the strong folding that affects the Palaeozoic sequence. The axial planes mostly verge to the NE (Harrington, 1947), the direction in which a decrease in the intensity of folding and metamorphic grade is also observed (von Gosen et al., 1990, 1991). The Ventania System was considered as an example of pure folding for decades (e.g. Harrington, 1947, 1970, 1972; Llambías and Prozzi, 1975). However, Schiller (1930) had already highlighted the importance of faulting in structuring the system. Varela et al. (1986), von Gosen et al. (1990), Cobbold et al. (1991), and Tomezzoli and Cristallini (1998) also supported this observation.

The deformation was considered to be of Permian-Early Triassic age on the basis of stratigraphic and structural criteria (e.g. Varela et al., 1985; Cobbold et al., 1986; Buggisch, 1987; von Gosen et al., 1990; López-Gamundí et al., 1995; Rossello et al., 1997). K-Ar dating on illites from the Curamalal Group yielded ages ranging from $282 \pm 3$ to $257 \pm 8$ Ma (Varela et al., 1985; Buggisch, 1987), which allowed the deformation to be assigned to the San Rafael Orogenic Phase (Azcuy and Caminos, 1987). Subsequent palaeomagnetic studies performed in the top unit of the Pillahuincó Group revealed that the lower part of the unit was deposited, deformed, and magnetized during the Early Permian (Tomezzoli, 1999, 2001; Tomezzoli and Vilas, 1999). Some authors argue that the deformation occurred in a unique phase during the Late Permian-Early Triassic (e.g. Japas, 1987), while others suggest that it took place in several phases during the Late Devonian-Early Carboniferous to the Permian (e.g. Massabie and Rossello, 1984; Tomezzoli, 2012).

\section{Geology of the Cerro Pan de Azúcar-Cerro del Corral area}

Cerro Pan de Azúcar and Cerro del Corral represent the SW and NE flanks, respectively, of a faulted overturned anticline along whose axis the erosive processes formed the Abra Meyer Valley (Varela et al., 1986). This narrow valley constitutes an erosive window that allows the basement rocks that underlie the Eopalaeozoic sedimentary rocks of La Lola and Mascota formations of the Curamalal Group to be recognized (Harrington, 1947) (Fig. 3). The name "Sauce Chico Inlier" is proposed here for this erosive window, alluding to the Sauce Chico Group, a stratigraphic unit defined by Cuerda et al. (1975) to designate the basement rocks that crop out in the Cerro Pan de Azúcar-Cerro del Corral area. The crystalline basement consists of cataclastic and mylonitic granites, mylonitic ignimbrites, a meta-andesite, and the Loma Marcelo skarn (Fig. 3). These rocks are the most deformed of the
Ventania System. Delpino and Dimieri (1992) and Delpino (1993) point out that the deformation and metamorphism would have reached temperatures ranging from 400 to $450{ }^{\circ} \mathrm{C}$ and pressures of about $200 \mathrm{MPa}$, conditions corresponding to the greenschist facies.

The meta-igneous rocks of the NE slope of Cerro Pan de Azúcar underlie the conglomerates and quartzites of La Lola and Mascota formations, respectively. These rocks are in normal position, and no evidence of intrusive contact between them and the meta-igneous rocks has been found (von Gosen et al., 1990). Cobbold et al. (1986) and Gregori et al. (2005) indicated that the contact between the crystalline basement and the overlying sedimentary cover is a thrust fault with a $\mathrm{NE}$ vergence, consistent with the tectonic nature attributed to this contact by Schiller (1930) and Cucchi (1966). The granitic ultramylonite belt, which allows a fault of $\mathrm{N} 340^{\circ} / 60^{\circ} \mathrm{SW}$ orientation to be inferred at Cerro Pan de Azúcar, is almost completely covered by debris from La Lola and Mascota formations and would not constitute the primary contact between the crystalline basement and the Palaeozoic sedimentary cover (Figs. 3 and 4). Less than $1.5 \mathrm{~km}$ to the NE from Cerro del Corral, the Mascota Formation crops out directly over the granitic mylonites. Consequently, the basement-Palaeozoic cover

contact would be an angular unconformity or a disconformity.

At Cerro del Corral, two N-S trending and west dipping shear zones with granitic and ignimbritic ultramylonites represent the tectonic contact between granite, ignimbrite, and La Lola Formation (Figs. 3 and 4). These shear zones converge toward the north, becoming a single fault with a N-S trend that tectonically juxtaposes the granite of Cerro 21 de Septiembre against La Lola Formation. Along the Cerro del Hueco-Cerro del Corral belt, the sedimentary sequence is inverted due to the overturning of the anticline towards the $\mathrm{NE}$ and $\mathrm{La}$ Lola Formation conglomeratic pebbles are deformed under ductile conditions (Schiller, 1930; Cucchi, 1966).

In the Sauce Chico Inlier, the NW-SE to N-S trending mylonitic foliation dips between 30 and $90^{\circ}$ to the SW-W, whereas the associated stretching lineation dips $47^{\circ}$ to the SSE (Fig. 4). The kinematic indicators reveal reverse dextral shearing with a top-to-NNW hanging wall. Post-tectonic quartz veins and veinlets ( \pm sericite, calcite, epidote, galena, and/or oxides) are discordant as well as parallel to the mylonitic foliation.

The Sauce Chico Inlier granites are cataclastic and mylonitic syenogranites and monzogranites characterized by heterogeneity and variation in colour and grain size (Fig. 5a, b). The less deformed granites of the area, which preserve the igneous primary features (e.g. equigranular texture), were identified at Loma Marcelo. The variable amount of sericite, chlorite, and muscovite of the matrix defines the schistosity of the granitic mylonites. SHRIMP U-Pb zircon dating revealed crystallization ages of $607.0 \pm 5.2 \mathrm{Ma}$ for the Cerro del Corral granite (Rapela et al., 2003) and 580.8 \pm 7.9 Ma for the Cerro Pan de Azúcar granite (Tohver et al., 2012). In addition, Tohver et al. (2012) reported a muscovite Ar-Ar age of $581 \pm 5$ Ma for the Cerro del Corral granite. These results indicate a Neoproterozoic timing for the Cerro Pan de Azúcar-Cerro del Corral granite emplacement.

The mylonitic ignimbrite of the Sauce Chico Inlier, of phenodacitic to phenorhyolitic composition, crops out in the eastern half of Cerro del Corral (Figs. 3 and 5c). It exhibits quartz and feldspar crystalloclasts (maximum length of 3-4 mm) immersed in a reddish-brown to greenish-grey aphanitic matrix (Fig. 5d) and has a texture marked by lens-shaped, greenish-grey fiammes (González et al., 2004). The contacts between ignimbrite, granite, and La Lola Formation are tectonic (Figs. 3 and 5 c). Therefore, field relationships do not allow determination of the relative age of the ignimbrite, which could be either older than the granite and a roof-pendant or younger and deposited on it. However, based on geochemical similarities, Ballivián Justiniano (2016) correlated the ignimbrite of Cerro del Corral with the alkaline granites of Cerro Colorado and Estancia Agua Blanca.

The meta-andesite of the Sauce Chico Inlier crops out 


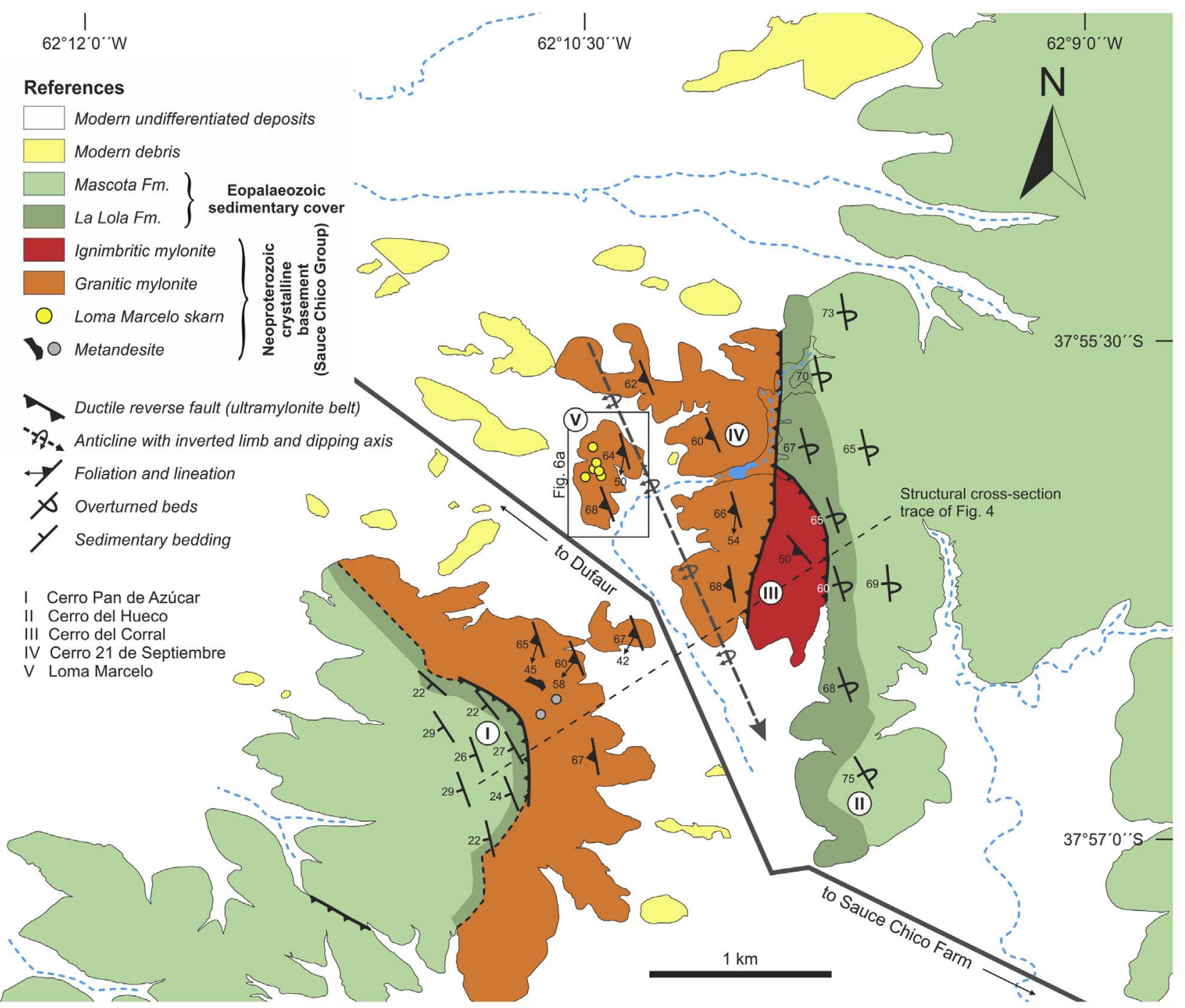

Fig. 3. Geological map of the Cerro Pan de Azúcar-Cerro del Corral area (Sauce Chico Inlier; modified from Cobbold et al. (1991)).

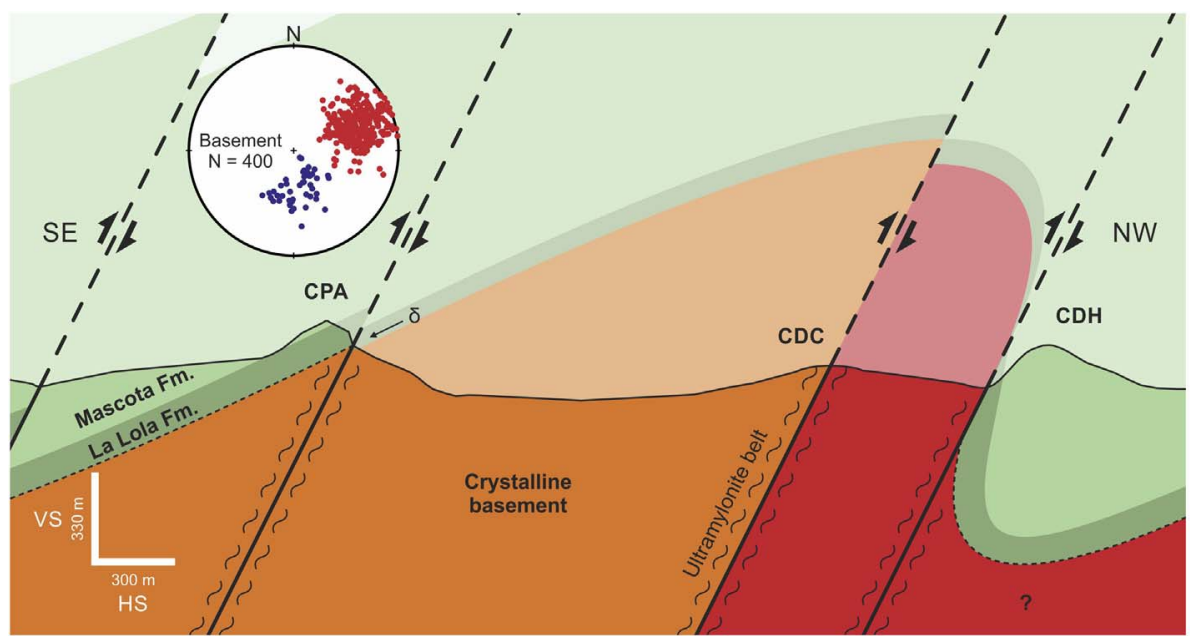

Fig. 4. Structural cross-section of the Sauce Chico Inlier. The red and blue circles of the stereoplot correspond to mylonitic foliation and lineation, respectively. Abbreviations: $\mathrm{CPA}=$ Cerro Pan de Azúcar, $\mathrm{CDC}=$ Cerro del Corral, $\mathrm{CDH}=$ Cerro del Hueco. (For interpretation of the references to colour in this figure legend, the reader is referred to the web version of this article.)

discontinuously in the NE slope of Cerro Pan de Azúcar (Figs. 3 and 5e). The largest outcrop is $80 \mathrm{~m}$ long and $30 \mathrm{~m}$ wide. The andesite has a porphyritic texture with large phenocrysts of greyish-white plagioclase, up to $4 \mathrm{~cm}$ in length, on a dark green aphanitic groundmass (Fig. $5 \mathrm{f}$ ). The andesite shows a pervasive foliation and its contact with the granitic rock, also foliated, is obscured by the deformation. Despite its elongated dyke-like shape and concordant relationship with the mylonitic foliation, unpublished magnetometric data do not show continuity of the main andesitic outcrop at depth, suggesting that it could be a roof-pendant. The porphyritic texture and vesicles are typical 

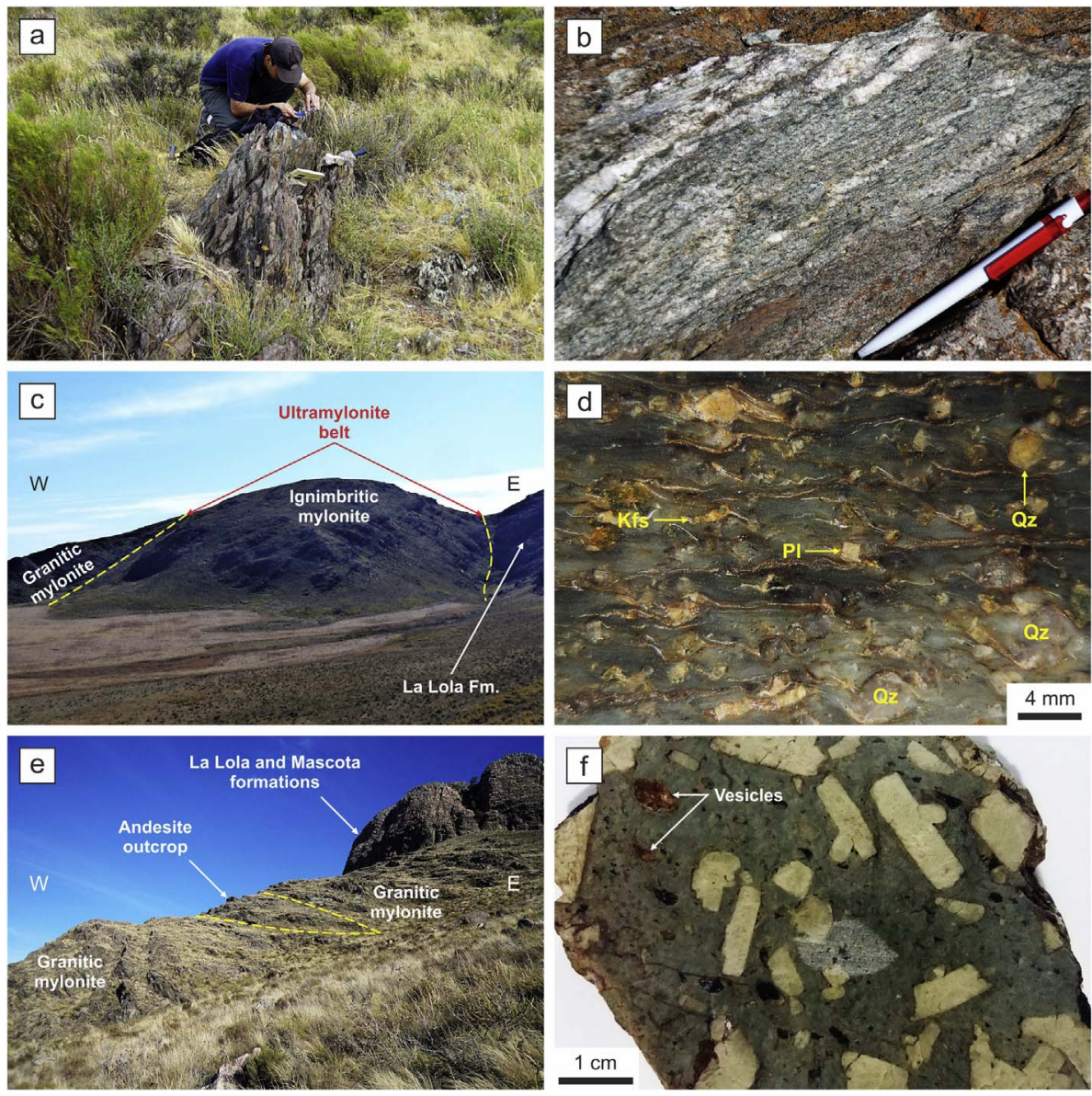

Fig. 5. a) Poor outcropping of the foliated granitic mylonite. b) Detail of quartz ribbons and drag folds in granitic mylonite. c) Location of the ignimbrite outcrop in the eastern half of Cerro del Corral. d) Polished hand sample of the ignimbrite in which some sigma- and delta-type porphyroclasts of feldspar and quartz show wings of the devitrified pyroclastic matrix. The dextral sense of shear can also be inferred from the small asymmetric folds turned to the left of the photograph. e) Location of the andesite outcrop in the northeastern slope of Cerro Pan de Azúcar. f) Polished hand sample of the andesite in which large phenocrysts of plagioclase and some vesicles are observed. Abbreviations: $\mathrm{Qz}=$ quartz, $\mathrm{Kfs}=\mathrm{K}$-feldspar, $\mathrm{Pl}=$ plagioclase . igneous features of shallow magma emplacement, thus indicating that the meta-andesite is either a lava flow or a subvolcanic body.

Calc-silicate and metacarbonate rocks that constitute de skarn crop out discontinuously at the Loma Marcelo area, a small hill of about $0.12 \mathrm{~km}^{2}$ (Fig. 6). Its host rock is mainly composed of cataclastic and protomylonitic granites intercalated with highly schistose belts of granitic mylonites. Calc-silicate rocks (calcic skarn) crop out, aligned in a NNW-SSE trend along $175 \mathrm{~m}$ in the central-western sector of the hill. The largest calc-silicate outcrop, $10 \mathrm{~m}$ long and $5 \mathrm{~m}$ wide, is lenticular in shape (LM-9 in Fig. 6). A metacarbonate rock (magnesian skarn), also of lenticular shape, is $2.8 \mathrm{~m}$ long and $2.2 \mathrm{~m}$ wide and crops out in the western side of the hill (LM-6 in Fig. 6). The calc-silicate and metacarbonate rocks constitute the Loma Marcelo skarn and are the study object of this paper.

\section{Materials and methods}

The lithogeochemical characterization was carried out on granite and skarn samples from the Sauce Chico Inlier. Major and trace elements were analysed by inductively coupled plasma mass spectrometry (ICP-MS) at Bureau Veritas Minerals Laboratories, Canada. The $\mathrm{C}$ and $\mathrm{S}$ contents were determined by infrared detection following combustion in a LECO analyser, whereas the F contents were determined by the potentiometric method with a LaF crystal membrane electrode.

Electron microprobe analyses were performed at two laboratories: 1) Departamento de Geología, Universidad de Oviedo, Spain, with a CAMECA Camebax SX-100 microprobe, and 2) Laboratorio de Microscopía Electrónica y Análisis por Rayos X (LAMARX), Universidad Nacional de Córdoba, Argentina, with a JEOL Superprobe JXA-8230 microprobe. Crystals of garnet, pyroxene, vesuvianite, titanite, chondrodite, and spinel from the Loma Marcelo skarn were analysed using a current acceleration of $15 \mathrm{kV}$, an electric current between 10 and $20 \mathrm{nA}$, and a beam diameter of $1-2 \mu \mathrm{m}$. Calibrations were performed using natural and synthetic standards.

One sample of the calcic skarn (11415, LM-9) was selected for laser ablation (LA)-ICP-MS U-Pb zircon dating. It was not possible to separate zircon grains from samples of the magnesian skarn. Concentration and separation of zircon grains were done at the Centro de Investigaciones Geológicas (CIG, CONICET-UNLP). A sample of $10 \mathrm{~kg}$ was crushed, washed, milled, and sieved. The heavy minerals were concentrated with a pan and then treated with a handheld magnet and Frantz isodynamic magnetic separator to concentrate the non-magnetic fraction. Zircon grains were handpicked in alcohol under a binocular microscope. The $\mathrm{U}-\mathrm{Pb}$ ages were obtained at the Centro de Pesquisas Geocronológicas (CPGeo), Universidade de São Paulo, Brazil, using a Thermo Fisher Neptune LA multicollector ICP-MS equipped with a 193 Photon laser system, following the analytical method described by Sato et al. (2010). Prior to LA-ICP-MS U-Pb analyses, the selected zircon grains were mounted in epoxy resin and their internal structure was exposed by polishing for dating.

Sm-Nd isotopic dating was performed at the Laboratório de Geocronologia, Universidade de Brasília, Brazil, on garnet-whole rock pairs of skarn samples 11415 and 19240 (both from LM-9) following the method described by Gioia and Pimentel (2000). The garnet and whole rock samples were finely powdered and their Sm and Nd contents were determined by X-ray fluorescence. Sm and Nd were extracted following conventional cation exchange techniques and then loaded on Re evaporation filaments of double filament assemblies. The isotopic measurements were carried out on a multicollector Finnigan MAT 262 


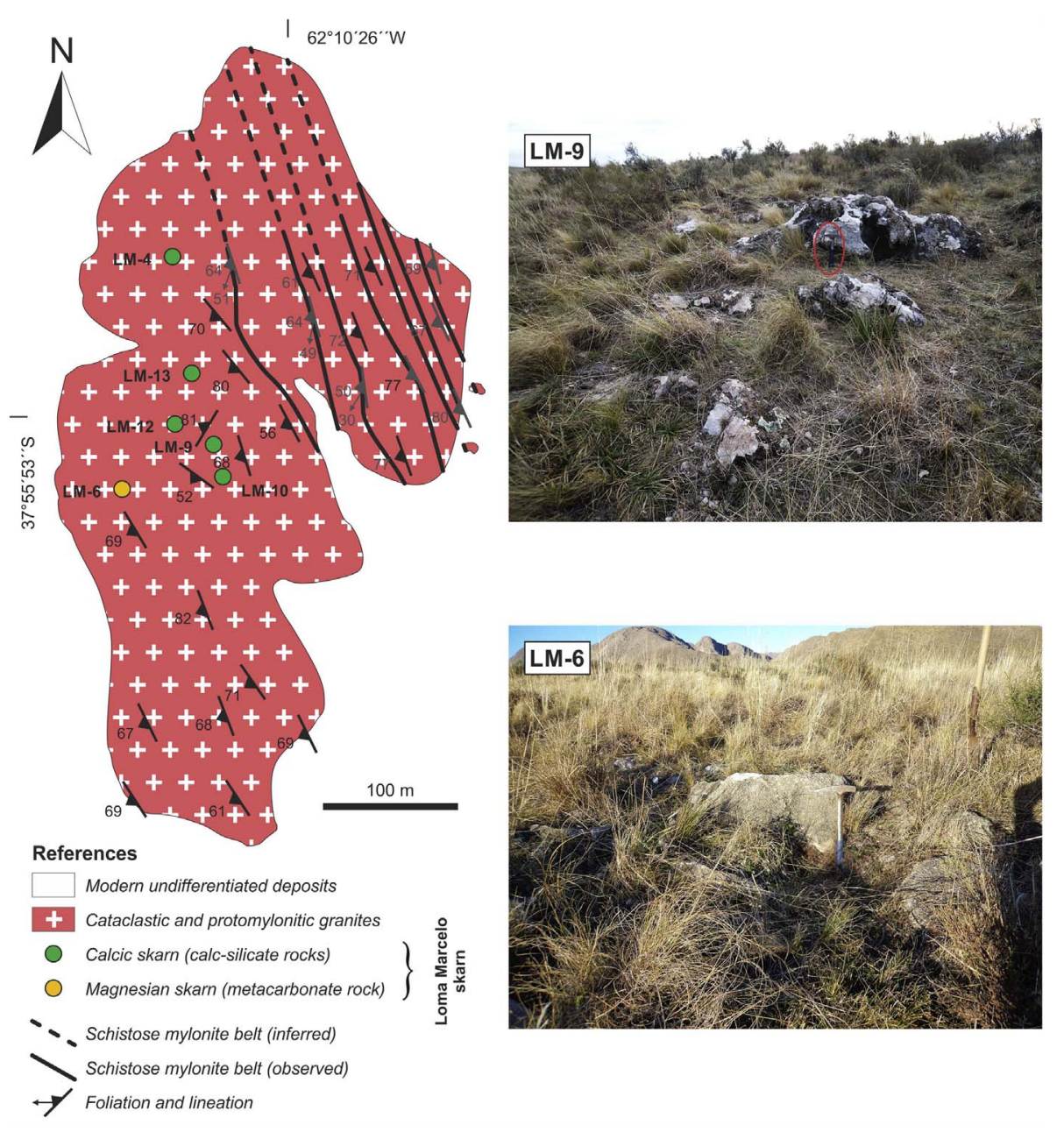

Fig. 6. Geological map of Loma Marcelo (modified from Ballivián Justiniano et al. (2015)) and outcrops of calc-silicate (LM-9) and metacarbonate (LM-6) rocks. The red oval in the photograph of LM-9 indicates a hammer placed to show the scale. mass spectrometer in static mode. The uncertainties for the ${ }^{147} \mathrm{Sm} /{ }^{144} \mathrm{Nd}$ and ${ }^{143} \mathrm{Nd} /{ }^{144} \mathrm{Nd}$ ratios are better than $\pm 0.2 \%(2 \sigma)$ and $\pm 0.005 \%(2 \sigma)$, respectively. ${ }^{143} \mathrm{Nd} /{ }^{144} \mathrm{Nd}$ ratios were normalized to an ${ }^{146} \mathrm{Nd} /{ }^{144} \mathrm{Nd}$ ratio of 0.7219 and the decay constant used was $\lambda^{147} \mathrm{Sm}=6.54 \times 10^{-12} \mathrm{a}^{-1}$.

$\mathrm{Rb}-\mathrm{Sr}$ isotopic dating was performed at the Centro de Pesquisas Geocronológicas, Universidade de São Paulo, Brazil, on a quartz-sericite pair of a vein that post-tectonically cuts the granitic mylonites of Loma Marcelo (sample 1819), following the method described by Kawashita (1972), as modified by Sato et al. (1995). The quartz and sericite samples were finely powdered and analysed by the isotope dilution method for determination of their $\mathrm{Rb}$ and $\mathrm{Sr}$ contents and ${ }^{87} \mathrm{Sr} /{ }^{86} \mathrm{Sr}$ ratios. The isotopic measurements were carried out on a multicollector VG-354 thermionic mass spectrometer using a Daly amplifier. Uncertainties are presented at $1 \sigma$ level for ${ }^{87} \mathrm{Rb} /{ }^{86} \mathrm{Sr}$ and at $2 \sigma$ level for ${ }^{87} \mathrm{Sr} /{ }^{86} \mathrm{Sr} .{ }^{87} \mathrm{Sr} /{ }^{86} \mathrm{Sr}$ ratios were normalized to an ${ }^{86} \mathrm{Sr} /{ }^{88} \mathrm{Sr}$ ratio of 0.1194 and the decay constant used was $\lambda^{87} \mathrm{Rb}=1.42 \times 10^{-11} \mathrm{a}^{-1}$.

The results of the Rb-Sr, Sm-Nd, and U-Pb analyses were plotted with Isoplot 4.15 (Ludwig, 2008).

Oxygen stable isotope determinations in silicates and oxides were performed at the Servicio General de Análisis de Isótopos Estables, Universidad de Salamanca, Spain. The analysed minerals were handpicked under a binocular microscope. The extraction of $\mathrm{O}_{2}$ from garnet, pyroxene, wollastonite, vesuvianite, chondrodite, and spinel from the Loma Marcelo skarn for isotopic analysis was performed by laser fluorination (Clayton and Mayeda, 1963), employing a Synrad $25 \mathrm{~W} \mathrm{CO}_{2}$ laser (Sharp, 1990) and reacting mineral powders with $\mathrm{ClF}_{3}$ reagent (e.g. Borthwick and Harmon, 1982). Isotope ratios were measured on a VG-Isotech SIRA-II dual inlet mass spectrometer. Both internal and international reference standards (NBS-28, NBS-30) were run to check accuracy and precision. Results are reported in $\delta^{18} \mathrm{O}$ notation relative to the Vienna Standard Mean Ocean Water (V-SMOW) using a $\delta^{18} \mathrm{O}$ value of $9.6 \%$ for NBS-28 (quartz) for the mass spectrometer calibration. The long-term reproducibility for repeated determination of reference samples was better than $\pm 0.2 \%$ o ( $1 \sigma)$.

\section{Petrography and mineral composition}

\subsection{Sauce Chico Inlier granites}

The Neoproterozoic granitic cataclasites and mylonites are the more widely exposed rocks in the Sauce Chico Inlier. They crop out in the NE slope of Cerro Pan de Azúcar, the western half of Cerro del Corral, Cerro 21 de Septiembre, and Loma Marcelo (Fig. 3).

\subsubsection{Cataclastic granites}

The cataclastic syenogranites are grey and medium to coarse grained (Fig.7a); a variety of coarse to very coarse grained granite was also identified. These granites are mainly composed of quartz, microcline, oligoclase, biotite, muscovite, and sericite (Fig. 7b). These are the rocks where the original protolith texture is better preserved.

Quartz crystals show dynamic and static recrystallization features. They are up to $2 \mathrm{~mm}$ in length and are small subhedral to euhedral crystals, approximately $40 \mu \mathrm{m}$ in diameter, with polygonal granoblastic texture (Fig. 7a, b).

Anhedral to subhedral feldspar crystals have millimetric size (Fig.7b). Microcline sometimes displays curved cross-hatched twinning and patches due to albite exsolution. The plagioclase (oligoclase, $\mathrm{An}_{14}$ ) 

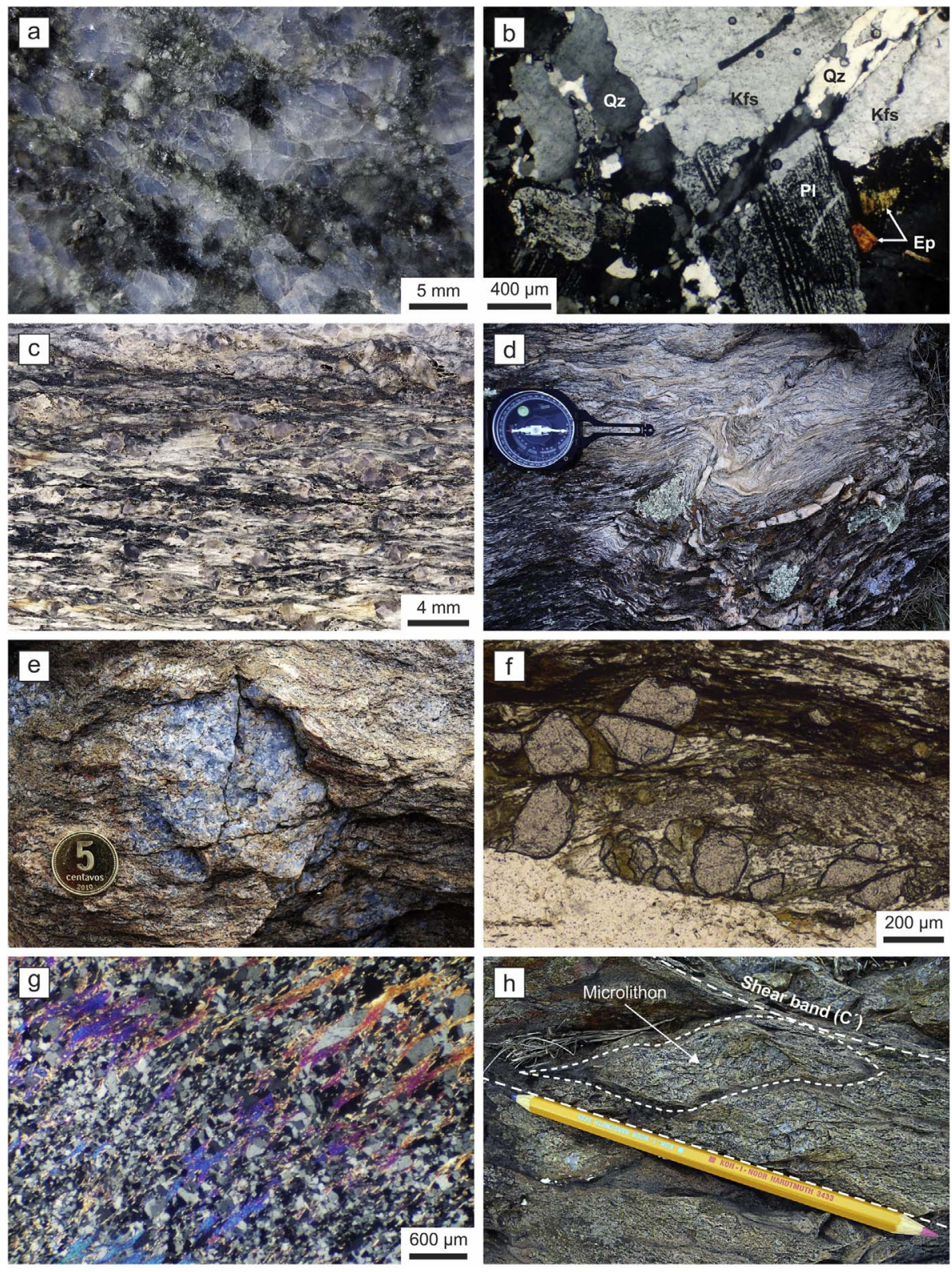

Fig. 7. a) Polished hand sample of the cataclastic-protomylonitic granite of Loma Marcelo. b) Cataclastic-protomylonitic granite in thin section (crossed Nicols view). Granular texture, interstitial quartz mosaics with granoblastic texture, and epidote as an accessory mineral phase are shown. Kinking in the polysynthetic twins of the in dicated plagioclase crystal is observed. Also, a microfracture that seems to displace the upper right end of the crystal is shown. c) Granitic mylonite of Cerro Pan de Azúcar. d) Ductile fault with quartz injections in granitic ultramylonite of Cerro 21 de Septiembre. e) Granitic porphyroclast surrounded by mylonitic matrix (Loma Marcelo). Coin diameter $=17.2 \mathrm{~mm}$. f) Fractured garnet crystals in the granitic mylonite of Cerro Pan de Azúcar (plane polarized light view). g) Fish foliation composed of muscovite in the granitic ultramylonite of Cerro 21 de Septiembre ductile fault (crossed Nicols view). h) Microlithon delimited by $\mathrm{C}^{\prime}$ type shear bands in the granitic mylonite of Loma Marcelo. Abbreviations: $\mathrm{Qz}=$ quartz, $\mathrm{Kfs}=\mathrm{K}$-feldspar, $\mathrm{Pl}=$ plagioclase, $\mathrm{Ep}=$ epidote shows curved and kinked polysynthetic twinning or antiperthites in the form of parallel veins.

Biotite and muscovite are scarce and are arranged in curved patterns that contour the quartz and feldspar crystals. Accessory minerals such as apatite, zircon, magnetite, epidote, and calcite were observed.

\subsubsection{Granitic mylonites}

The Sauce Chico Inlier granitic mylonites are brownish-red, greenish-grey, or green in colour and have been classified as protomylonites, mylonites, and ultramylonites. The protomylonites and mylonites are the dominant rocks (Fig. 7c), while the ultramylonites constitute discrete belts coincident with the ductile faults (Fig. 7d). Rhomboidal, lenticular, or banded porphyroclasts of the syenogranitic protolith are commonly included in the mylonitic matrix of protomylonites and mylonites (Fig. 7e).

The protomylonitic granites consist of quartz-feldspathic porphyroclasts settled in a matrix predominantly composed of sericite, chlorite, and muscovite, along with minor biotite, quartz, and feldspar. The mylonites have abundant micaceous minerals and scarce porphyroclasts of feldspar. In both protomylonites and mylonites, fractured crystals of garnet can also be observed (Fig. 7f). Accessory minerals are apatite, zircon, magnetite, and epidote.

The ultramylonites are fine-grained rocks with continuous foliation defined by preferentially oriented muscovite, chlorite, sericite, and quartz grains (Fig. 7g). The transition between the different types of mylonites is sharp, reflecting strong gradients in the intensity of the deformation. Evidences of pressure dissolution, intracrystalline deformation, recovery, and recrystallization processes were observed.

The pressure dissolution and the subsequent redeposition of the dissolved material are evidenced by pressure shadows and dark bands of insoluble materials concentrated along the mylonitic foliation. The intracrystalline deformation and recovery are mainly evidenced by undulating extinction, deformation lamellae, and deformation bands in the quartz crystals. The deformation mechanisms identified in the granitic mylonites suggest low-grade metamorphic conditions during mylonitization (temperature between 350 and $400{ }^{\circ} \mathrm{C}$; lower part of the greenschist facies).

Shear sense indicators are C- and $\mathrm{C}^{\prime}$-type shear bands (Fig. 7h), oblique foliation in quartz, sigma-type mantled feldspars, mica 

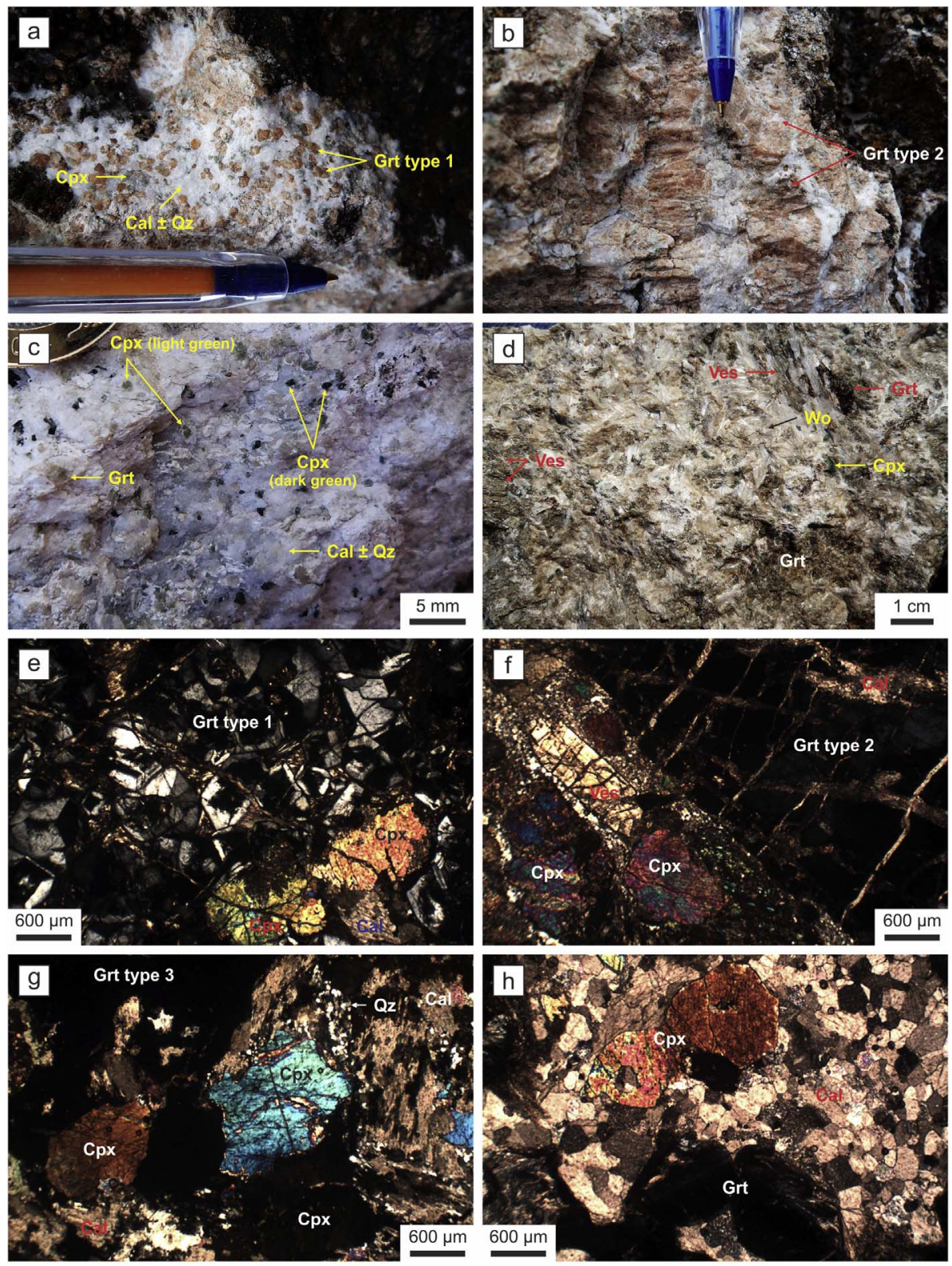

Fig. 8. Outcrops of the calcic skarn showing variable colours as a function of the dominant calc-silicate minerals. Reddish pink (a,b) and yellowish pink (c) garnet crystals, dark green and light green clinopyroxene crystals (a, c, d), and crystals of wollastonite and vesuvianite (d) can be observed. In thin section, diverse mineral associations mainly composed of distinct types of garnet and clinopyroxene are seen [(e-h), crossed Nicols views]. Additionally, in (f) and (h), a prismatic fractured crystal of vesuvianite and the recrystallized calcitic matrix, respectively, are exhibited. Abbreviations: $\quad \mathrm{Grt}=$ garnet,$\quad \mathrm{Cpx}=$ clinopyroxene, Ves $=$ vesuvianite, $\mathrm{Cal}=$ calcite, $\mathrm{Qz}=$ quartz. (For interpretation of the references to colour in this figure legend, the reader is referred to the web version of this article.) fish (muscovite), and boudinated and domino-type magnetite porphyroclasts. All of these indicate that the granites of the Sauce Chico Inlier, like the other basement rocks, were affected by dextral shearing.

\subsection{Loma Marcelo skarn}

\subsubsection{Calc-silicate rocks (calcic skarn)}

Boudins of calc-silicate rocks are aligned parallel to the mylonitic foliation of the metagranites (Fig. 6). The colour of calc-silicate rocks is very variable (Fig. 8), ranging from greyish white and reddish pink to greyish green. They are composed of garnet, clinopyroxene, scapolite, plagioclase, wollastonite, vesuvianite, and calcite, among other minerals. The grain size is medium to coarse and the textures vary from granoblastic to porphyroblastic.

Garnets were classified into three types, named 1, 2, and 3 (Ballivián Justiniano et al., 2015) (Fig. 8a, b, e-g). Type 1 garnet consists of subhedral to euhedral crystals with diameters of up to $500 \mu \mathrm{m}$, anomalous anisotropy, and hourglass-shaped twins. Type 2 garnet forms irregular centimetric masses with anomalous anisotropy and strong fracturing. Some subhedral to euhedral crystals with oscillatory zoning were identified within the masses. Type 3 garnet forms mosaics of euhedral dodecahedral crystals approximately $100 \mu \mathrm{m}$ in diameter, completely isotropic, and scarcely fractured. Crystals of type 3 garnet were also identified inside irregular cavities, together with calcite and/or quartz.

Two types of clinopyroxene, of dark green and light green colours, were clearly identified in hand specimens (Ballivián Justiniano et al., 2015) (Fig. 8c). Dark green clinopyroxene is anhedral and subrounded and has maximum lengths of approximately $4 \mathrm{~mm}$. The light green clinopyroxene appears as subhedral to euhedral crystals and reaches lengths of up to 6-7 mm. The dark green clinopyroxene is more altered and fractured than the light green one. The different types of pyroxene and garnet are part of a different paragenesis, which will be discussed in Section 9.1.

Scapolite and plagioclase were identified as meionite and bytownite, respectively. Wollastonite is recognized by its fibrous habit (Fig. 8d). The vesuvianite appears in four varieties, coloured green, brownish green, brown, and blue (Fig. 8d). The green and brown 

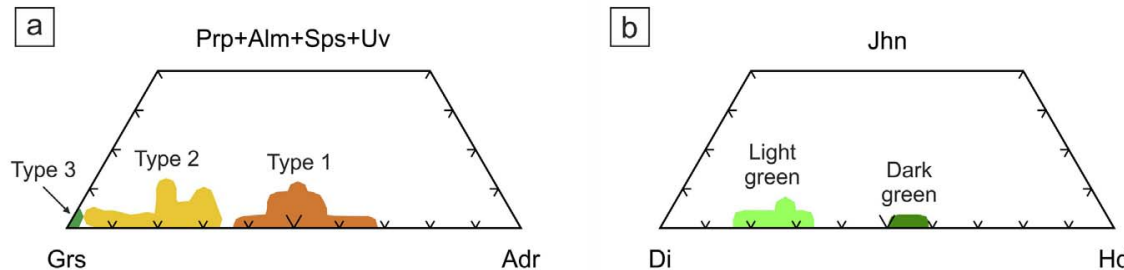
Adr
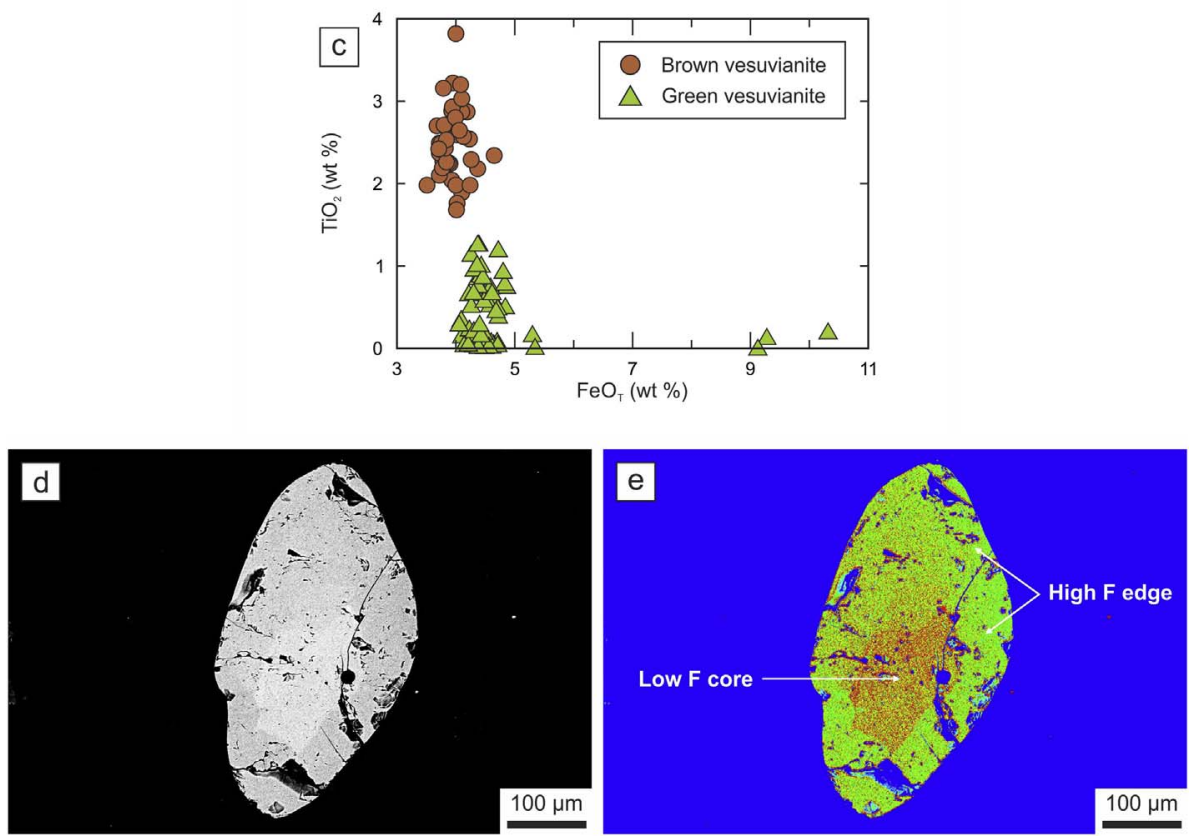

Fig. 9. a) Ternary plot of garnet composition from the calcic skarn. End members: Grs = grossular, Adr = andradite, Prp $=$ pyrope,$\quad$ Alm $=$ almandine,$\quad$ Sps $=$ spessartine, $\mathrm{Uv}=$ uvarovite. b) Ternary plot of clinopyroxene composition from the calcic skarn. End members: $\mathrm{Di}=$ diopside, $\mathrm{Hd}=$ hedenbergite, $\mathrm{Jhn}=$ johannsenite. c) $\mathrm{TiO}_{2}$ vs. $\mathrm{FeO}_{\mathrm{T}}$ diagram of vesuvianite from the calcic skarn. d) Backscattered electron image of a titanite crystal from the calcic skarn with compositional zoning. e) Titanite crystal of the previous figure in false colours. (For interpretation of the references to colour in this figure legend, the reader is referred to the web version of this article.) varieties exhibit radiating-prismatic habit, while the blue one is interstitial and very scarce.

The matrix is scarce and composed of calcite that ranges from 1 to $2 \mathrm{~mm}$ in diameter (Fig. $8 \mathrm{~h}$ ) with granoblastic texture. Titanite is a frequent retrograde mineral that often exhibits concentric zonation. Quartz, epidote, apatite, and zircon are present as minor constituents. Galena is a minor component in a quartz veinlet that cuts the calc-silicate rocks.

A millimetre-wide banding was identified in the calc-silicate rocks, consisting of whitish bands that are mainly composed of calcite and/or wollastonite, interspersed with reddish and greenish bands composed of garnet and clinopyroxene. In addition, a penetrative foliation of NW-SE/85-90 ${ }^{\circ}$ SW orientation was recognized, together with the existence of lattice-preferred orientation in calcite crystals of the skarn matrix (Ballivián Justiniano et al., 2015).

Electron microprobe analysis allowed garnets to be classified as grandite and clinopyroxenes as salite. Type 1 garnet is andraditic grossular (Grs (F.54-91.84\% $\mathrm{Adr}_{4.08-21.39 \%}$ ), whereas the type 2 ( $\mathrm{Grs}_{90.03-98.84 \%} \mathrm{Adr}_{0.00-9.71 \%}$ ) and type 3 garnets ( $\mathrm{Grs}_{97.22-99.82 \%}$ $\mathrm{Adr}_{0.00 \%}$ ) are more grossularitic (Fig. 9a; Supplementary Material 1). The dark green clinopyroxene is diopsidic hedenbergite ( $\mathrm{Di}_{42.81-47.17 \%}$ $\mathrm{Hd}_{52.39-56.66 \%}$ ) and the light green clinopyroxene is hedenbergitic diopside $\left(\mathrm{Di}_{67.90-81.25 \%} \mathrm{Hd}_{17.88-31.34 \%}\right)$ (Fig. 9b; Supplementary Material 2). The green and brown colours of the vesuvianites are a consequence of their different contents of $\mathrm{Fe}$ and $\mathrm{Ti}$, in agreement with the observations made by Manning (1975). The green vesuvianite has high $\mathrm{FeO}_{\mathrm{T}}(4.06-5.34 \%)$ and low $\mathrm{TiO}_{2}(\leq 1.24 \%)$ contents, while the brown vesuvianite has slightly lower contents of $\mathrm{FeO}_{\mathrm{T}}(3.51-5.34 \%)$ and $\mathrm{TiO}_{2}$ contents of up to $3.82 \%$ (Fig. 9c; Supplementary Material 3). The blue vesuvianite could not be analysed by electron microprobe because of its small grain size; however, its colour could be due to the occurrence of small amounts of Cu (Fitzgerald et al., 1986). The F content reaches up to $2.70 \%$. The titanite crystals present compositional zoning, with low-F cores (1.73\%) and more enriched rims (2.12-2.47\%) (Fig. 9d, e; Supplementary Material 4).

\subsubsection{Metacarbonate rock (magnesian skarn)}

The metacarbonate rock is found in the western sector of Loma Marcelo. It is mainly composed of chondrodite and spinel porphyroblasts included in a calcite + dolomite matrix with granoblastic texture and dynamic recrystallization of grain boundaries (Fig. 10a).

Chondrodite is pale yellow to orange-yellow in hand specimens and exhibits orange fluorescence under short-wave ultraviolet light (Fig. 10b). The chondrodite crystals are anhedral and slightly elongated $(\leq 8 \mathrm{~mm})$; they are intensely fractured and have high relief and simple or polysynthetic twins (Fig. 10c). Spinel is bluish grey to violet, subhedral to euhedral, and reaches diameters of up to $3 \mathrm{~mm}$ (Fig. 10d, f). The crystals of chondrodite and spinel are incipiently replaced by dozyite $\left[\left(\mathrm{Mg}_{7} \mathrm{Al}_{2}\right)\left(\mathrm{Si}_{4} \mathrm{Al}_{2}\right) \mathrm{O}_{15}(\mathrm{OH})_{12}\right]$ and these three minerals show a variable degree of serpentinization. Dozyite has laminar habit, perfect cleavage, and undulating extinction (Fig. 10e). In addition, fluorite grains were identified within fractures and along the grain boundaries of chondrodite, spinel, and dozyite crystals (Fig. 10f). Other minerals identified are quartz and small inclusions of pyrite and Co-pyrite inside chondrodite crystals. 

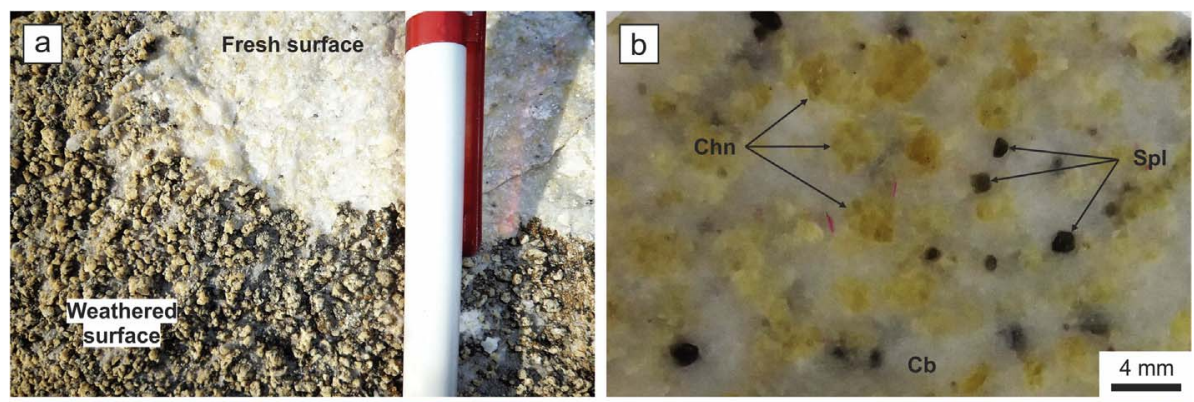

Fig. 10. a) Weathered and fresh surfaces of the magnesian skarn in the outcrop. b) Polished fresh hand specimen of the magnesian skarn. c) Twinned chondrodite in thin section (crossed Nicols view). d) Spinel sensu stricto in thin section surrounded by carbonate matrix with granoblastic texture (plane polarized light view). e) Dozyite in thin section (crossed Nicols view). f) Spinel, chondrodite, and interstitial fluorite (backscattered electron image). Abbreviations: Chn $=$ chondrodite,$\quad$ Spl $=$ spinel sensu stricto, $\mathrm{Cb}=$ carbonate $\quad$ (calcite + dolomite),$\quad$ Dzy $=$ dozyite $\mathrm{Fl}=$ fluorite.
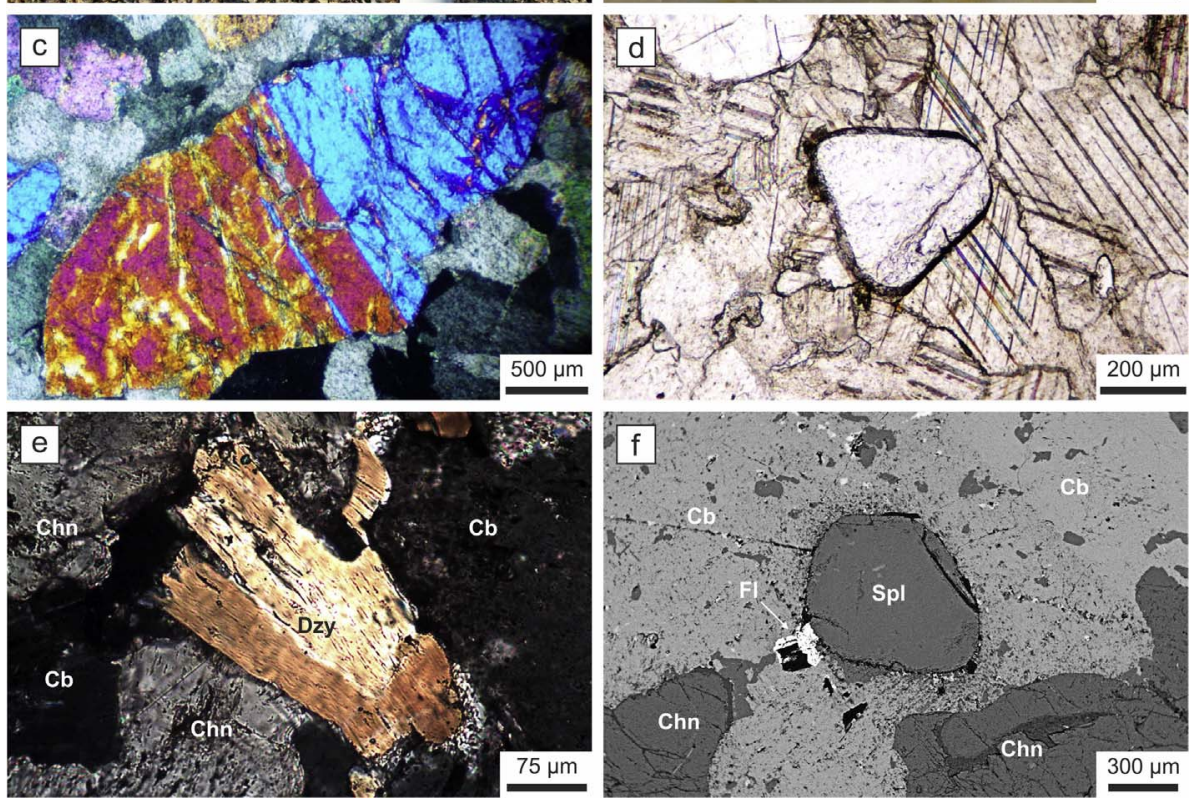

The general formula of the Loma Marcelo skarn chondrodite can be

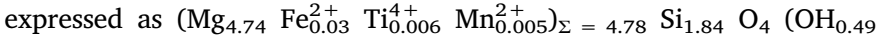
$\left.\mathrm{F}_{1.51}\right)_{\Sigma}=2.00$ (Supplementary Material 5). Note the high $\mathrm{F}$ content ( $8.69 \%$ on average). Neither other humite-group minerals nor forsterite were identified by X-ray diffraction analysis or electron microprobe in samples of the metacarbonate rock.

The spinel of the metacarbonate rock consists mainly of spinel sensu stricto $\left(\mathrm{Spl}_{95.86-97.12 \%}\right.$ ). The replacement of $\mathrm{Mg}$ by Fe${ }^{2+}, \mathrm{Mn}$, and $\mathrm{Zn}$ is reduced, with the molecular proportions of hercynite, galaxite, and gahnite being less than $5 \%$. The general formula of the Loma Marcelo skarn spinel can be expressed as $\left(\mathrm{Mg}_{7.64} \mathrm{Fe}_{0.27}^{2+} \mathrm{Mn}_{0.02} \mathrm{Zn}_{0.008}\right)_{\Sigma}=7.94$ $\left(\mathrm{Al}_{15.99} \mathrm{Fe}_{0.01}^{3+} \mathrm{Cr}_{0.009}\right)_{\Sigma}={ }_{16.00} \mathrm{O}_{32}$ (Supplementary Material 6).

\section{Lithogeochemistry}

Major and trace elements were determined in granite and skarn samples from the Sauce Chico Inlier. The complete results of the analysed samples are presented in Supplementary Material 7 and 8.

\subsection{Sauce Chico Inlier granites}

The cataclastic granites (samples 11413 and 19245) from Loma Marcelo have $73-74 \% \mathrm{SiO}_{2}$ and plot within the sub-alkaline field of the $\mathrm{SiO}_{2}$-alkalis diagram of Irvine and Baragar (1971). These rocks are peraluminous, with values of the alumina saturation index [ASI $=$ molar $\left.\mathrm{Al}_{2} \mathrm{O}_{3} /\left(\mathrm{CaO}+\mathrm{Na}_{2} \mathrm{O}+\mathrm{K}_{2} \mathrm{O}\right)\right]$ of 1.09 and 1.17 and normative corundum of 1.38 and 2.33\% (Supplementary Material 7). The cataclastic granites are the less deformed granitic rocks at the Sauce Chico Inlier. When plotted using the Ab-An-Or diagram (Barker, 1979), the analysed samples fall within the granite field (Fig. 11a).

Primitive mantle-normalized spidergrams of cataclastic granite samples exhibit a marked enrichment in incompatible elements with respect to the most compatible elements, as well as negative anomalies of $\mathrm{Th}, \mathrm{U}, \mathrm{Nb}$, and $\mathrm{Ta}$ and positive anomalies of $\mathrm{Rb}, \mathrm{K}, \mathrm{Pb}$, and $\mathrm{Eu}$ (Fig. 11b). The total REE reaches 49.86-64.95 ppm (Supplementary Material 7). Chondrite-normalized REE patterns indicate strong enrichment of LREE $\left(\mathrm{La}_{\mathrm{N}} / \mathrm{Lu}_{\mathrm{N}}=36.74\right.$ and 149.47) and positive Eu anomalies ( $\mathrm{Eu} / \mathrm{Eu}^{*}=2.81$ and 3.07) (Fig. 11c). In relation to the REE pattern of the upper crust, that of the cataclastic granites exhibits a similar Eu concentration and is slightly depleted in the other REE.

The analysed samples of granitic mylonite (19198 and CPA-1) from Loma Marcelo and Cerro Pan de Azúcar have lower $\mathrm{SiO}_{2}, \mathrm{Na}_{2} \mathrm{O}$, and $\mathrm{K}_{2} \mathrm{O}$ contents and higher contents of the other oxides and loss on ignition (LOI) relative to the cataclastic granites (Supplementary Material 7). These mylonites plot within the sub-alkaline field of the $\mathrm{SiO}_{2}$-alkalis diagram and are peraluminous, with alumina saturation index of 1.10 and 3.17 and normative corundum contents of 1.64 and 15.58\% (Supplementary Material 7).

Primitive mantle-normalized spidergrams of granitic mylonite samples are similar to those of the cataclastic granites; however, granitic mylonites have a slightly higher content of HREE. The total REE reaches 159.89-180.61 ppm (Supplementary Material 7). In relation to the cataclastic granites, the chondrite-normalized REE patterns of the granitic mylonites show similar slopes for the LREE and flatter slopes for the HREE $\left(\mathrm{La}_{\mathrm{N}} / \mathrm{Lu}_{\mathrm{N}}=7.29\right.$ and 17.69) (Fig. 11c). The $\mathrm{Eu}$ anomalies are negative $\left(\mathrm{Eu} / \mathrm{Eu}^{*}=0.60\right.$ and 0.72$)$ and the general REE patterns are identical to those of the upper crust.

When plotted in tectonic discrimination diagrams, the cataclastic granite and granitic mylonite samples fall within the volcanic arc and syncollisional fields of the Y-Nb and Yb-Ta diagrams of Pearce et al. (1984) (Fig. 11d) and in the S-I-type field of the Ga/Al versus $\mathrm{Zr}$ diagram of Whalen et al. (1987) (Fig. 11e). 

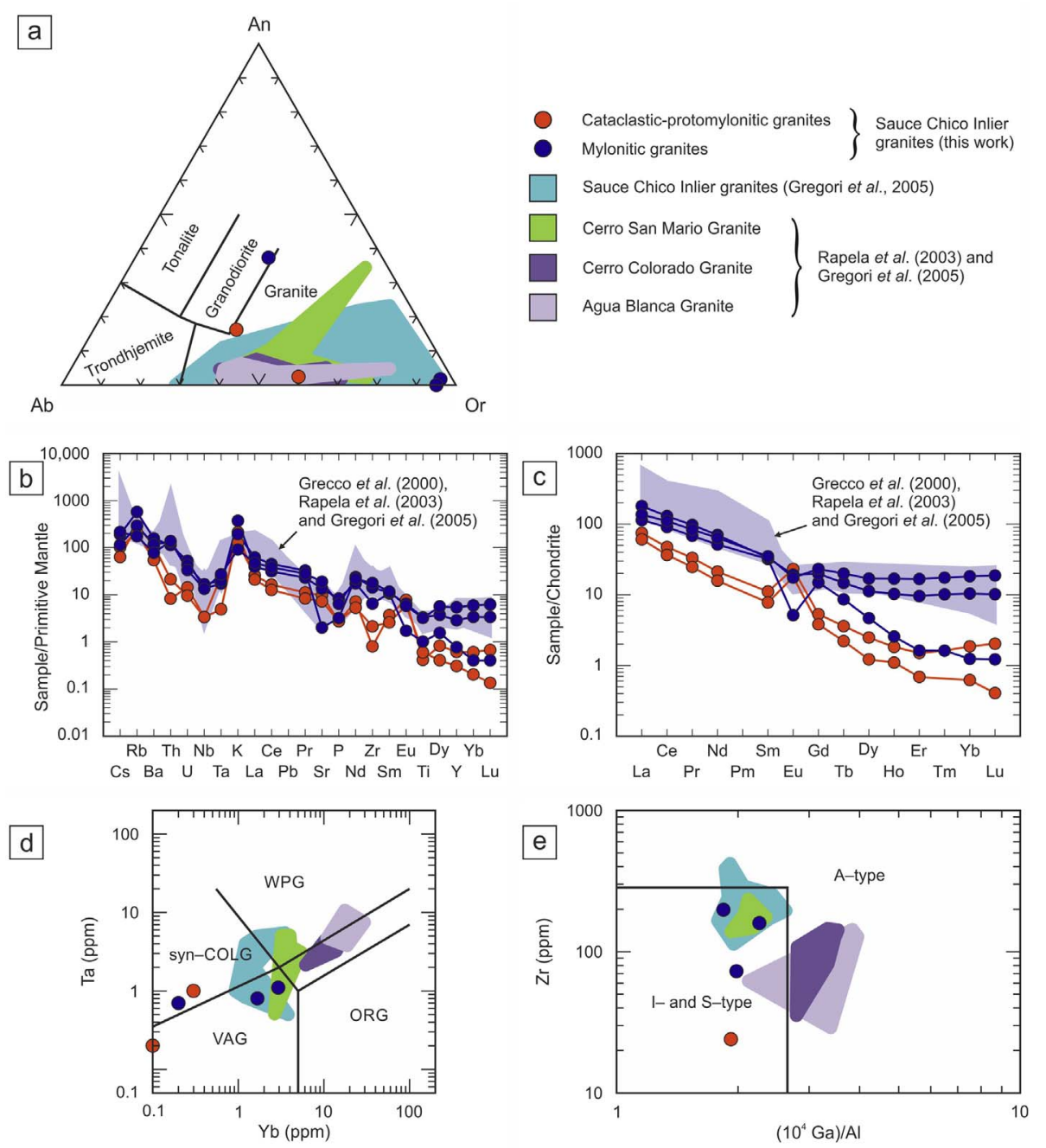

Fig. 11. a) Ab-An-Or ternary plot (Barker, 1979) of selected granitic rock samples from the Sauce Chico Inlier. b) Trace element diagram normalized to primitive mantle values (Sun and McDonough, 1989) for the granitic rock samples. c) Rare earth element diagram normalized to chondrite values (McDonough and Sun, 1995) for the granitic rock samples. Discrimination diagrams for the granitic rock samples: d) $\mathrm{Ta}$ vs. $\mathrm{Yb}$ discrimination diagram for within-plate granites (WPG), volcanic-arc granites (VAG), syn-collision granites (syn-COLG), and ocean-ridge granites (ORG) (Pearce et al., 1984). e) $\mathrm{Zr}$ vs. $\left(\mathrm{Ga} \times 10^{4}\right) / \mathrm{Al}$ discrimination diagram for A- and S-I-type granites (Whalen et al., 1987).
The cataclastic granites have positive Eu anomalies and smaller REE contents than the granitic mylonites analysed by Gregori et al. (2005) (Fig. 11c). The geochemical characteristics of cataclastic granites would respond to primary igneous features resulting from their collisional genesis, interpreted by Rapela et al. (2003) as the closure of the Adamastor Ocean during the Neoproterozoic. The strong enrichment of LREE suggests that garnet remained as a residual phase during melting of the parent rocks. The positive Eu anomalies can be explained by crystallization of plagioclase from a liquid relatively impoverished in Eu due to prior fractionation of this element at the source (Korhonen et al., 2010).

An $\varepsilon \mathrm{Nd}_{607}$ value of -9.2 and a depleted mantle model age of 1974 Ma suggest a Palaeoproterozoic crustal component in the source region of the Neoproterozoic granites (Rapela et al., 2003). These authors pointed out that the anatectic reworking of the Palaeoproterozoic rocks of the Tandilia System would be the most probable source of the Neoproterozoic granites of the Ventania System. In accordance with this hypothesis, Tohver et al. (2012) dated two zircons from the alkaline granite of Estancia Agua Blanca, which revealed a SHRIMP $\mathrm{U}-\mathrm{Pb}$ age of $2182 \pm 18 \mathrm{Ma}$, interpreted as inheritance. The Rhyacian age is within the time interval corresponding to the magmatic climax (ca. 2250-2120 Ma) recorded in the basement of the Río de la Plata Craton in the Tandilia System (Cingolani, 2011).

The increase of the total REE content in the granitic mylonites of the
Sauce Chico Inlier would be a consequence of the extreme mobility of elements associated with mylonitization of the basement rocks of the Ventania System and with the crystallization of accessory mineral phases such as epidote (Grecco et al., 2000).

\subsection{Loma Marcelo skarn}

The metasomatic influx of chemical elements into the carbonate system resulted in a calcic skarn (calc-silicate rocks) and a magnesian skarn (metacarbonate rock), depending on the different compositions of carbonate protoliths. The two types of skarns have similar $\mathrm{CaO}$ contents but different amounts of $\mathrm{SiO}_{2}, \mathrm{TiO}_{2}, \mathrm{Al}_{2} \mathrm{O}_{3}, \mathrm{Fe}_{2} \mathrm{O}_{3}, \mathrm{MgO}$ and LOI, and low contents of $\mathrm{Cr}_{2} \mathrm{O}_{3}, \mathrm{MnO}, \mathrm{Na}_{2} \mathrm{O}, \mathrm{K}_{2} \mathrm{O}$, and $\mathrm{P}_{2} \mathrm{O}_{5}$ (Figs. 12 and $13 \mathrm{a}$, b; Supplementary Material 7). Contents of $0.76-1.99 \%$ C, less than $0.02 \%$ $\mathrm{S}$, and about $0.27 \% \mathrm{~F}$ were detected in the calcic skarn. On the other hand, contents of $7.45-9.10 \% \mathrm{C}$, less than $0.05 \% \mathrm{~S}$, and $1.69 \% \mathrm{~F}$ were identified in the magnesian skarn. In the calcic skarn, $\mathrm{Ca}, \mathrm{Al}, \mathrm{Fe}$, and $\mathrm{Mg}$ are concentrated in the silicate minerals (e.g. garnet, clinopyroxene, wollastonite, and vesuvianite), whereas in the magnesian skarn, Ca is concentrated in the carbonate matrix (mainly of calcitic composition) and $\mathrm{Mg}$ in the chondrodite and spinel. Very low concentrations of elements of economic interest (e.g. precious and base metals) were detected in both skarn types (Supplementary Material 7).

The variability of $\mathrm{SiO}_{2}$ and LOI (Supplementary Material 7) in the 

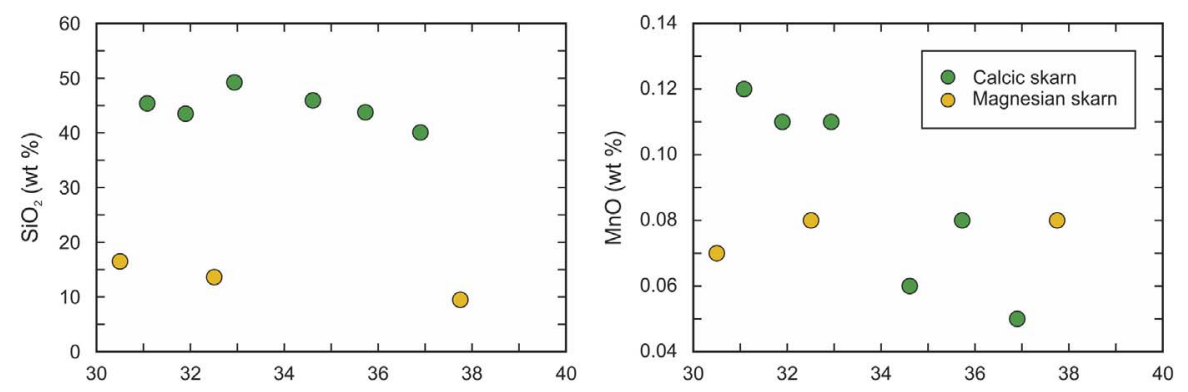

Fig. 12. Bivariant diagram plots for the Loma Marcelo skarn.
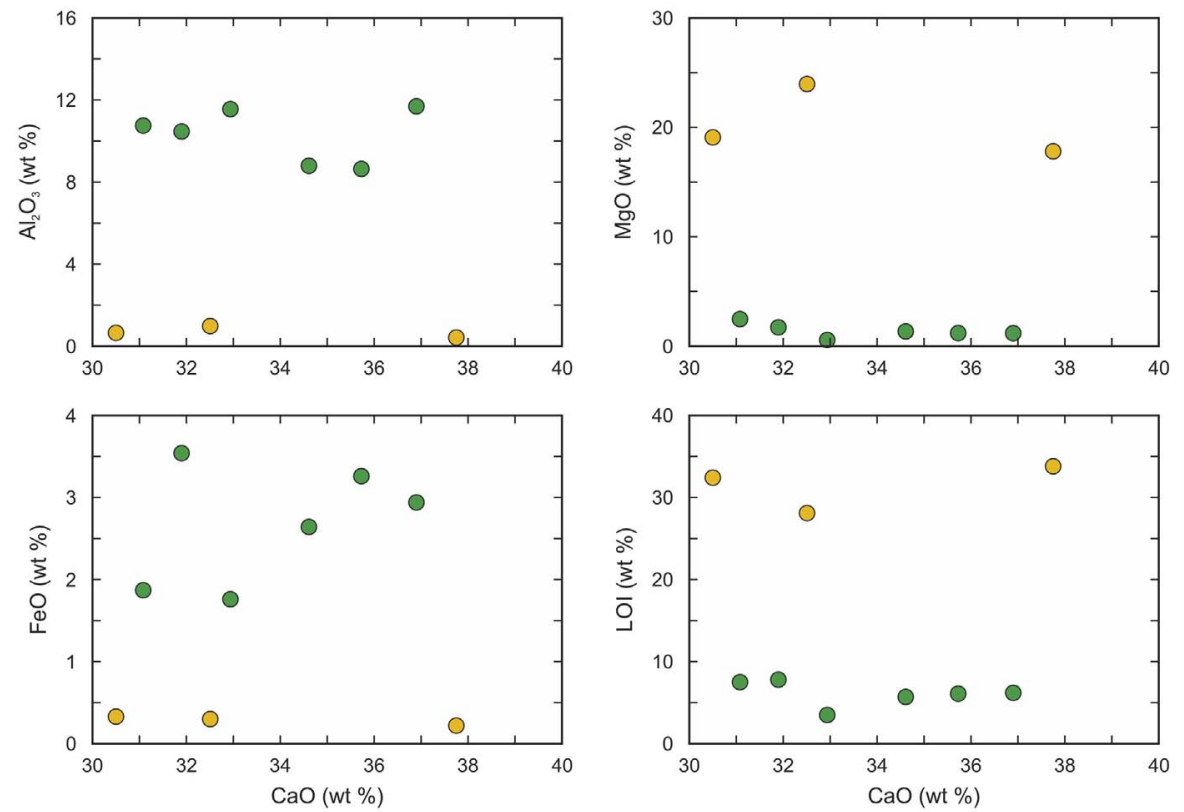

calcic and magnesian skarns is due to their different proportions of silicate and carbonate minerals. There is an inverse relationship between the two variables: high $\mathrm{SiO}_{2}$ contents are related to low LOI contents, which is linked to the fact that the greater the proportion of silicates, the smaller the proportion of carbonates. The silicates and carbonates constitute 88.0 and $12.0 \%$ of the calcic skarn, respectively, whereas they represent 32.5 and $67.5 \%$ of the magnesian skarn. The lower percentages of carbonates would be a consequence of the consumption of calcite and quartz by the majority of the reactions triggered during the prograde metamorphism and the concomitant decrease in the modal content of both minerals. In this way, this rock would have lost much of its carbonate minerals, turning into a calc-silicate rock.

Dolomitic protoliths are generally Fe-poor, and ferromagnesian minerals of their metamorphic equivalents commonly have compositions with $\mathrm{X}_{\mathrm{Mg}}>0.95\left[\mathrm{X}_{\mathrm{Mg}}=\mathrm{Mg} /(\mathrm{Fe}+\mathrm{Mg})\right]$. For this reason, the amount of $\mathrm{Fe}$ is negligible in most dolomite marbles and magnesian skarns. This fact can be seen in the chemical composition of the Loma Marcelo skarn through the $\mathrm{Mg}$ number $[\mathrm{Mg} \#=$ $(100 \times \mathrm{MgO}) /(\mathrm{FeO}+\mathrm{MgO})]$, which has values of about $98.60 \%$ in the magnesian skarn and between 24.10 and $56.89 \%$ in the calcic skarn (Supplementary Material 7). The mainly calcitic composition of the magnesian skarn matrix would be related to the consumption of dolomite during the prograde metamorphism, favouring the concentration of calcite in the matrix and the concomitant decrease in the modal content of dolomite.

Upper-crust-normalized spidergrams of skarn samples show little fractionation of incompatible elements relative to more compatible ones and negative anomalies of $\mathrm{Rb}, \mathrm{Ba}, \mathrm{K}$, and $\mathrm{Ni}$ in the calcic skarn. $\mathrm{Rb}$,
$\mathrm{K}$, and Ti behave similarly in the magnesian skarn (Fig. 13c, d). In the patterns of the two types of skarns, it can be seen that the concentration of trace elements is greater in the calcic skarn than in the magnesian skarn by approximately one order of magnitude. The total REE reaches 44.28-110.15 ppm in the calcic skarn and $10.47-28.79 \mathrm{ppm}$ in the magnesian skarn (Supplementary Material 7). Chondrite-normalized REE patterns indicate enrichment of LREE $\left(\mathrm{La}_{\mathrm{N}} / \mathrm{Lu}_{\mathrm{N}}=3.53-14.65\right)$ and negative Eu anomalies $\left(\mathrm{Eu} / \mathrm{Eu}^{*}=0.33-0.85\right)$ (Fig. 13e). Although the calcic skarn is characterized by the presence of garnet in sometimes considerable quantities, the occurrence of this mineral is not reflected in its flat to negative slopes of the HREE patterns $\left(\mathrm{Tb}_{\mathrm{N}} /\right.$ $\mathrm{Lu}_{\mathrm{N}}=0.97-1.85$ ), suggesting a low content and/or little fractionation of these elements in the garnet from the Loma Marcelo skarn.

\section{Geochronology}

\section{1. $L A-I C P-M S U-P b$ in zircons}

The zircons separated from the calcic skarn sample 11415 are translucent, colourless to brownish, and have prismatic and subrounded shapes. Some crystals are intensely metamictized. In order to determine the internal structure of the zircon crystals, micrographs with transmitted polarized light and normal reflected light and backscattered electron images (SEM) were obtained. The analysis of the different types of images revealed oscillatory zoning, thorite inclusions, and/or xenocrystalline cores in some crystals (Fig. 14).

Twenty-three spots were analysed by LA-ICP-MS (Supplementary Material 8). When plotted on the Wetherill concordia diagram (Fig. 15a), the 23 points exhibit variable degrees of discordance and 
a

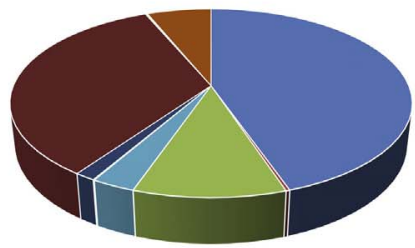

$\mathrm{b}$

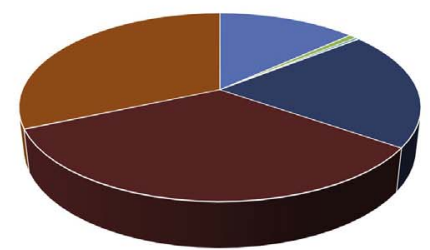

Fig. 13. Pie diagrams of the major element composition for the calcic [(a), average of six samples] and magnesian [(b), average of three samples] skarn. Trace element diagrams normalized to upper crust values (Taylor and McLennan, 1985) for the calcic (c) and magnesian (d) skarn. e) Rare earth element diagram normalized to chondrite values (McDonough and Sun, 1995) for the Loma Marcelo skarn (the crosses correspond to the upper crust values of Taylor and McLennan (1985)).
$\mathrm{SiO}_{2}$
$\mathrm{TiO}_{2}$
$\mathrm{Al}_{2} \mathrm{O}_{3}$
$\mathrm{MgO}$
$\mathrm{CaO}$
$\mathrm{Na}_{2} \mathrm{O}$
$\mathrm{Cr}_{2} \mathrm{O}_{3} \square \mathrm{Fe}_{2} \mathrm{O}_{3}$
$\mathrm{K}_{2} \mathrm{O} \square \mathrm{P}_{2} \mathrm{O}_{5}$

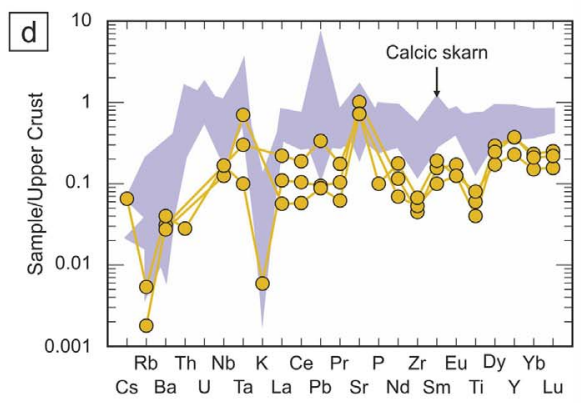

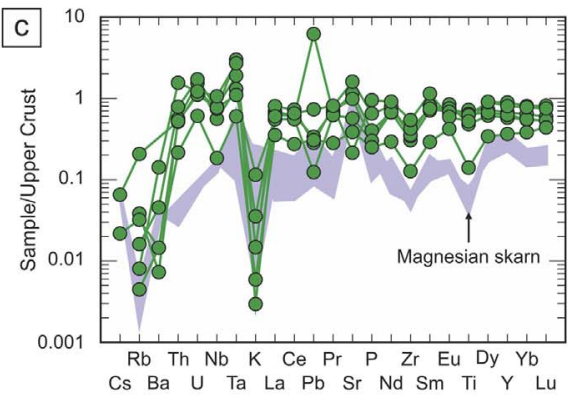
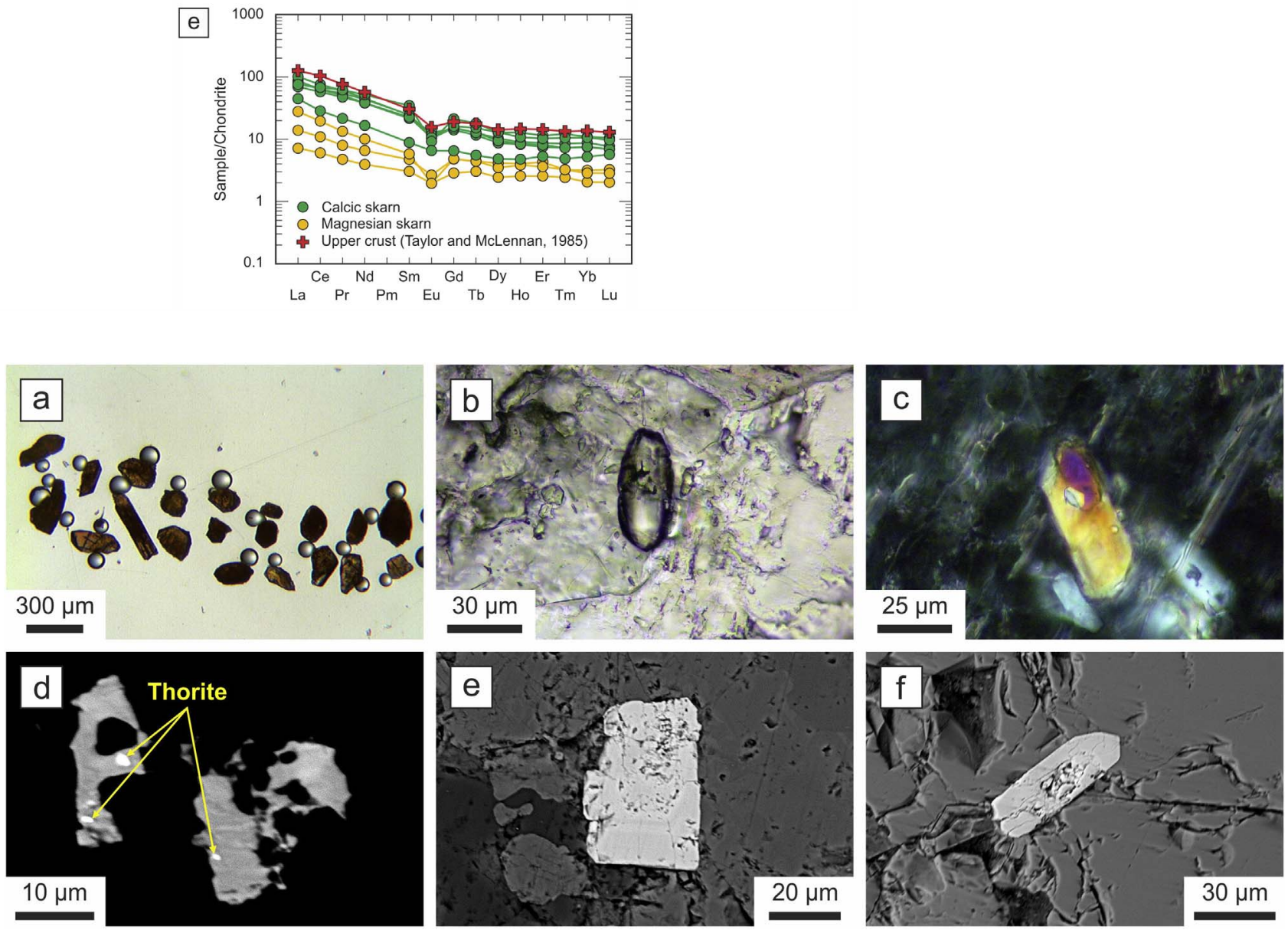

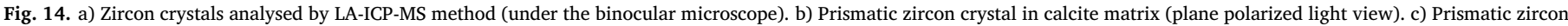

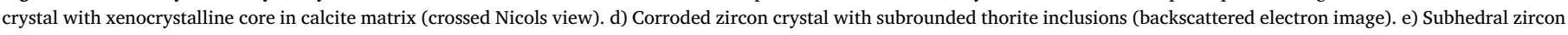
crystal with oscillatory zoning (backscattered electron image). f) Backscattered electron image of a zircon crystal included in garnet. 
a
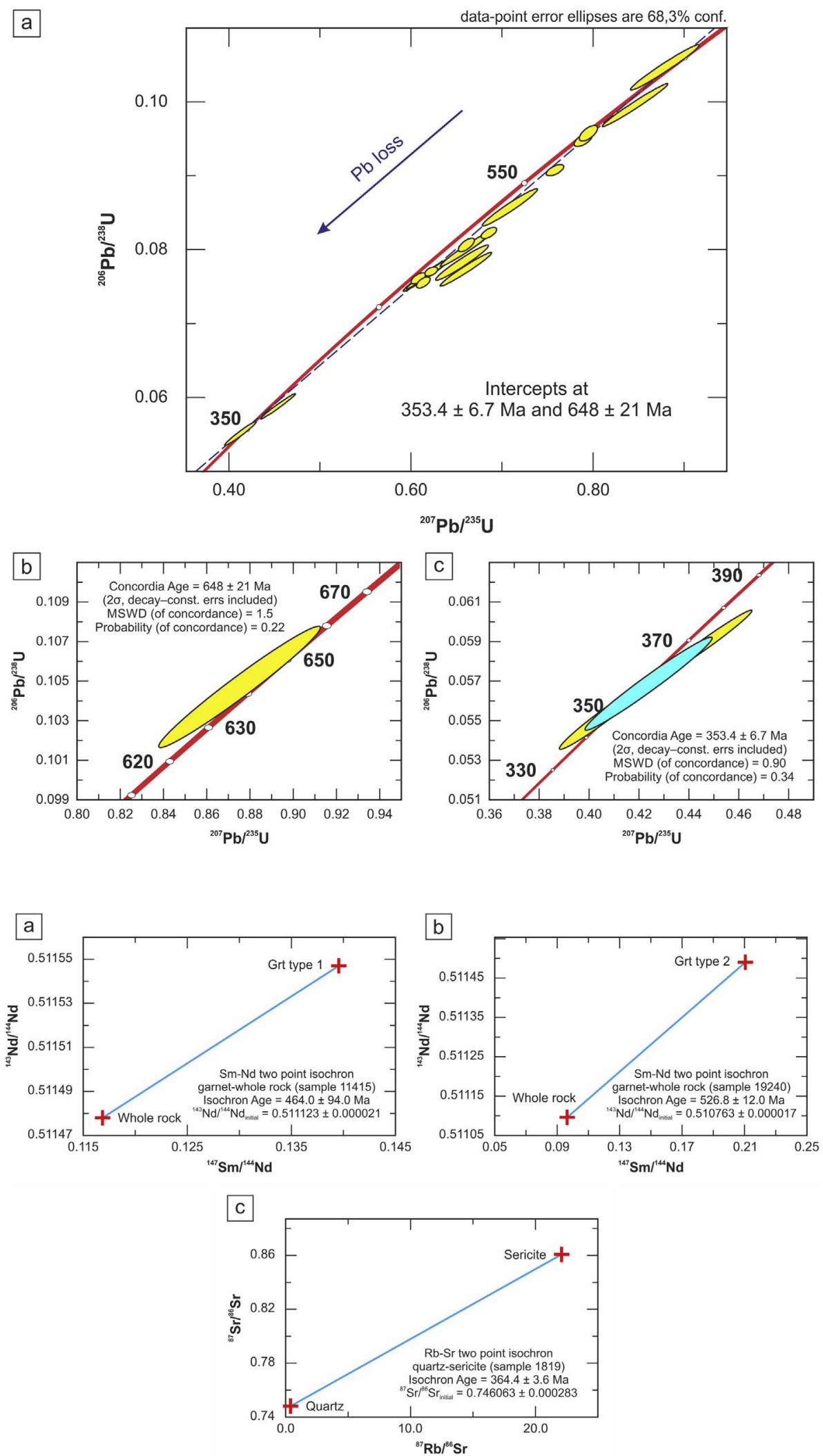

define a discordia line close to the concordia line. A single zircon defines an upper intercept age of $648 \pm 21 \mathrm{Ma} \quad(\mathrm{MSWD}=1.5)$ (Fig. 15b), whereas two zircons define a lower intercept age of $353.4 \pm 6.7 \mathrm{Ma}(\mathrm{MSWD}=0.90)$ (Fig. 15c). The upper intercept age would correspond to the crystallization age of the analysed zircon,
Fig. 15. a) Wetherill concordia plot of LA-ICP-MS zircon data for the calcic skarn. b) Detail of the concordia upper intercept. c) Detail of the concordia lower intercept.
Fig. 16. a) Sm-Nd two point isochron for the type 1 garnetwhole rock pair of the calcic skarn. b) Sm-Nd two point isochron for the type 2 garnet-whole rock pair of the calcic skarn. c) Rb-Sr two point isochron for the quartz-sericite pair of a quartz \pm sericite vein that cuts the granitic mylonites in the southern sector of Loma Marcelo. whereas the ages lower than around $600 \mathrm{Ma}$ are interpreted as resulting from $\mathrm{Pb}$ loss due to metamorphism and deformation. The lower intercept age would correspond to the tectonothermal event responsible for such a loss. 


\subsection{Sm-Nd garnet-whole rock isochrons}

Skarn samples 11415 and 19240 were analysed by the Sm-Nd method and two-point isochrons were constructed from the analytical results of concentrates of garnet types 1 (11415) and 2 (19240) and their corresponding whole rock (WR) samples (Supplementary Material 9). Type 3 garnet could not be concentrated because of its small grain size and lack of magnetic susceptibility. Garnets are very resistant minerals, characterized by their low REE contents and by fractionation of these elements during their formation, increasing their HREE content and conferring a higher Sm/Nd ratio (Cordani et al., 2005). It is for this reason that garnets have been widely used in the Sm-Nd isotopic dating of garnetiferous metamorphic rocks (e.g. Griffin and Brueckner, 1980; Vance and O'Nions, 1990).

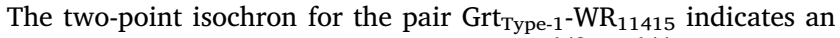
age of $464.0 \pm 94.0 \mathrm{Ma}$ with an initial ${ }^{143} \mathrm{Nd} /{ }^{144} \mathrm{Nd}$ ratio of $0.511123 \pm 0.000021$ (Fig. 16a), whereas the two-point isochron for the pair $\mathrm{Grt}_{\text {Type- } 2}-\mathrm{WR}_{19240}$ indicates an age of $526.8 \pm 12.0 \mathrm{Ma}$ with an initial ${ }^{143} \mathrm{Nd} /{ }^{144} \mathrm{Nd}$ ratio of $0.510763 \pm 0.000017$ (Fig. 16b). The Terreneuvian age determined for the type 2 garnet-whole rock pair coincides with the age of the Early Cambrian alkaline magmatism of the Ventania System ( $c a$. 533-524 Ma). On the other hand, the Darriwilian age determined for the type 1 garnet-whole rock pair has no geological meaning since in the Ventania System there are no records of igneous or metamorphic activity of Ordovician age. The 464 Ma mean can be interpreted as a resetting age due to opening of the Sm-Nd isotopic system that occurred during the Early Cambrian.

\section{3. $\mathrm{Rb}$-Sr quartz-sericite isochron}

Sample 1819 comes from a quartz \pm sericite vein that post-tectonically cuts the granitic mylonites in the southern sector of Loma Marcelo. This sample was analysed by the Rb-Sr method and a two-point isochron was constructed from the analytical results of concentrates of quartz and sericite (Supplementary Material 10). The different degree of fractionation of $\mathrm{Rb}$ and $\mathrm{Sr}$ in these minerals is responsible for the higher $\mathrm{Rb} / \mathrm{Sr}$ ratio of the sericite, allowing the quartz-sericite pair to be used as a geochronometer. Both elements constitute impurities in quartz, while $\mathrm{Rb}$ is the main substitute for $\mathrm{K}$ in micas.

The Rb-Sr two-point isochron indicates an age of $364.4 \pm 3.6 \mathrm{Ma}$ with an initial ${ }^{87} \mathrm{Sr} /{ }^{86} \mathrm{Sr}$ ratio of $0.746063 \pm 0.000283$ (Fig. 16c). This Famennian age is close to the Tournaisian age of $353.4 \pm 6.7 \mathrm{Ma}$ recorded in the Loma Marcelo skarn zircons. Using new decay constants, Varela et al. (1990) recalculated the Rb-Sr and K-Ar ages obtained by Cingolani and Varela (1973) and Varela and Cingolani (1976) in basement rocks of the Ventania System. Among the recalculated ages, an age of $360 \pm 21 \mathrm{Ma}$ (Rb-Sr, whole rock) was obtained for peralkaline rhyolites from Cerro La Ermita and Estancia La Mascota. Varela and Cingolani (1976) interpreted this age as a result of resetting of the isotope system.

\section{Stable isotopes}

Oxygen stable isotope determinations in garnet, clinopyroxene, wollastonite, vesuvianite, chondrodite, and spinel from the Loma Marcelo skarn are plotted in Fig. 17 and listed in Supplementary Material 11. The $\delta^{18} \mathrm{O}$ values of garnets from LM-9 and LM-13 vary between +5.1 and $+8.1 \%$. LM- 4 garnet is the most enriched $\left(\delta^{18} \mathrm{O}=\right.$ $+12.5 \%$ ), whereas LM-10 garnet is the most depleted $\left(\delta^{18} \mathrm{O}=-2.9 \%\right.$ ). Clinopyroxene exhibits a wide range of $\delta^{18} \mathrm{O}$ values, varying from $-6.6 \%$ (LM-9) to $+9.3 \%$ (LM-4), as does wollastonite $\left(\delta^{18} \mathrm{O}=+5.8 /+19.3 \%\right)$. The $\delta^{18} \mathrm{O}$ values of vesuvianite from different outcrops are between +7.3 and $+8.4 \%$, exhibiting very little variation. In LM- 6 , the values of $\delta^{18} \mathrm{O}$ are +11.0 and $+11.5 \%$ or the chondrodite and $+15.1 \%$ for the spinel.

Some of the values shown in Supplementary Material 11 are anomalous and not of primary nature, such as those from LM-10 (especially garnet and wollastonite). Clinopyroxene from LM-9 is depleted in ${ }^{18} \mathrm{O}$. Vesuvianite, however, presents similar values in all samples.

The wide range of $\delta^{18} \mathrm{O}$ values would indicate water-rock interaction processes. On the other hand, differences in absolute $\delta^{18} \mathrm{O}$ values suggest that the fluid nature was diverse, or that if a single type of fluid interacted with the minerals, it did so under varying temperatures and water-rock ratios, among other factors.

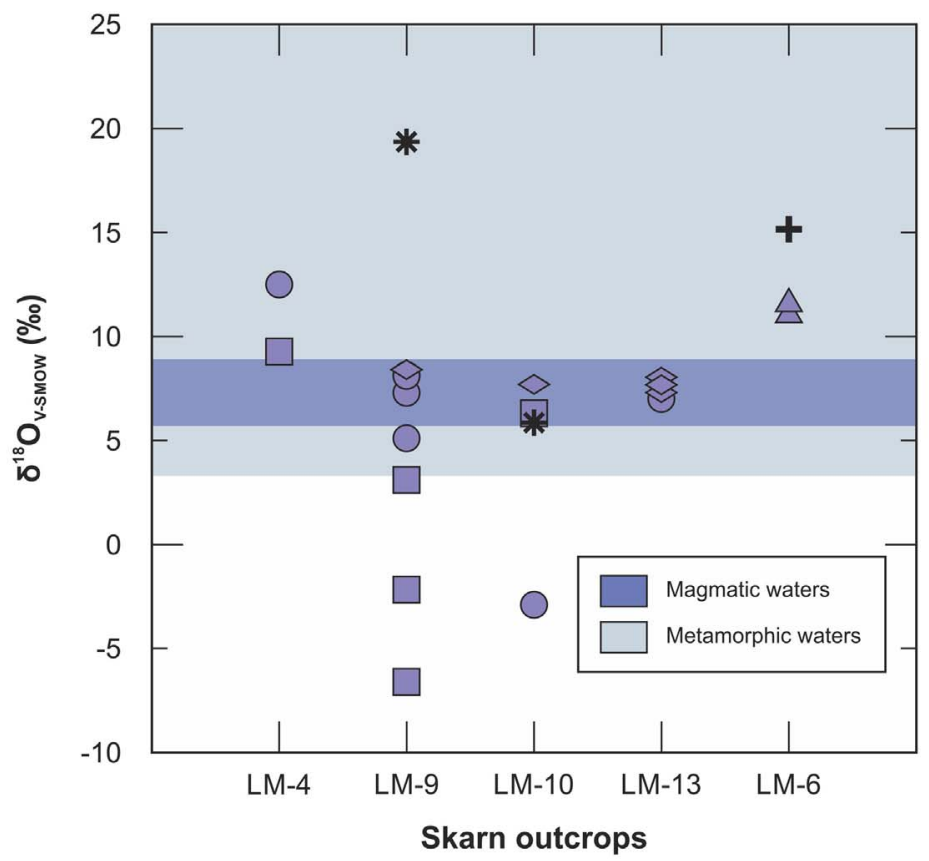

Fig. 17. Stable isotope determinations of oxygen in silicates and oxides from the Loma Marcelo skarn. The fields of magmatic and metamorphic waters (Rollinson, 1993) are shown for comparative purposes. 
Table 1

Paragenetic prograde sequence for the Loma Marcelo skarn.

\begin{tabular}{|c|c|c|c|}
\hline $\begin{array}{l}\text { Event } \\
\text { Age (Ma) }\end{array}$ & $\begin{array}{c}\text { M1 }^{\mathrm{a}} \\
\text { ca. } 607\end{array}$ & $\begin{array}{c}\mathrm{M} 2^{\mathrm{b}} \\
\text { ca. } 527\end{array}$ & $\begin{array}{c}\text { M3 }^{\mathrm{c}} \\
\text { ca. } 364-353\end{array}$ \\
\hline \multicolumn{4}{|c|}{ Calcic skarn } \\
\hline Garnet & 0 & 0 & 0 \\
\hline Clinopyroxene & 0 & 0 & \\
\hline Wollastonite & 0 & & \\
\hline Scapolite & - & & \\
\hline Plagioclase & 0 & & \\
\hline Vesuvianite & & 0 & \\
\hline Calcite & 0 & - & - \\
\hline \multicolumn{4}{|c|}{ Magnesian skarn } \\
\hline Forsterite (?) & 0 & & \\
\hline Spinel & 0 & & \\
\hline Chondrodite & & 0 & \\
\hline Dolomite & 0 & 0 & 0 \\
\hline Calcite & 0 & 0 & 0 \\
\hline
\end{tabular}

${ }^{a}$ Neoproterozoic S-type granite intrusion and contact metamorphism of carbonate xenoliths and skarn formation.

b Post-magmatic hydrothermalism related to Early Cambrian A-type magmatism and Fmetasomatism of the skarn.

${ }^{\mathrm{c}}$ Regional metamorphism and mylonitization of basement rocks.

\section{Discussion}

\subsection{The Loma Marcelo skarn and its polymetamorphic history}

On the basis of the above results integrated with previous studies, we link the genesis of the Loma Marcelo skarn to three overlapping metasomatic events associated with the circulation of fluids of both igneous and metamorphic origin. The first event (M1) is related to the intrusion of the Neoproterozoic S-type granite and the incorporation of carbonate xenoliths by the intrusion. The second event (M2) is linked to the Early Cambrian alkaline magmatism (e.g. Cerro Colorado and Estancia Agua Blanca granites). The third event (M3) is related here to a possible regional metamorphism of Late Devonian-Early Carboniferous age responsible for the mylonitization of the basement rocks of the Ventania System.

The protoliths of the Loma Marcelo skarn may have been incorporated during the intrusion of the Neoproterozoic granite ( $c a$. 607-581 Ma; Rapela et al., 2003; Tohver et al., 2012) and metasomatized in the first instance by their magmatic fluids. This M1 event is represented by type 1 garnet, dark green clinopyroxene, wollastonite, meionite, and bytownite in the calcic skarn (Table 1). Since the skarn is included within the granite, the maximum temperature reached during the M1 event should have been about $700{ }^{\circ} \mathrm{C}$, the temperature around which granitic magmas crystallize. In water-rich siliceous carbonate rocks and under closed system conditions, wollastonite begins to form at $600{ }^{\circ} \mathrm{C}$ and its stability field extends above $700{ }^{\circ} \mathrm{C}$ at $200 \mathrm{MPa}$ (Bucher and Grapes, 2011).

The M2 event was responsible for fluorine influx into the Neoproterozoic basement, for the formation of type 2 garnet, light green clinopyroxene, and vesuvianite in the calcic skarn, and for the generation of chondrodite in the magnesian skarn (Table 1). The chondrodite would have formed by hydration of forsterite, a mineral that, together with the spinel, would have constituted the high-temperature paragenesis formed during the M1 event in the magnesian skarn. At low pressures, the humite-group minerals do not require unusual temperatures or fluid compositions to be stable in metamorphosed carbonate rocks, with the availability of $\mathrm{F}$ in the protolith and/or in metasomatic fluids being the most important factor determining their occurrence (Rice, 1980). The lack of forsterite in the magnesian skarn suggests its consumption during the chondrodite-generating reactions.

The high contents of $\mathrm{F}$ in minerals such as vesuvianite (up to $2.70 \%$ $\mathrm{F})$ and chondrodite (8.69\% $\mathrm{F}$ on average) indicate the development of
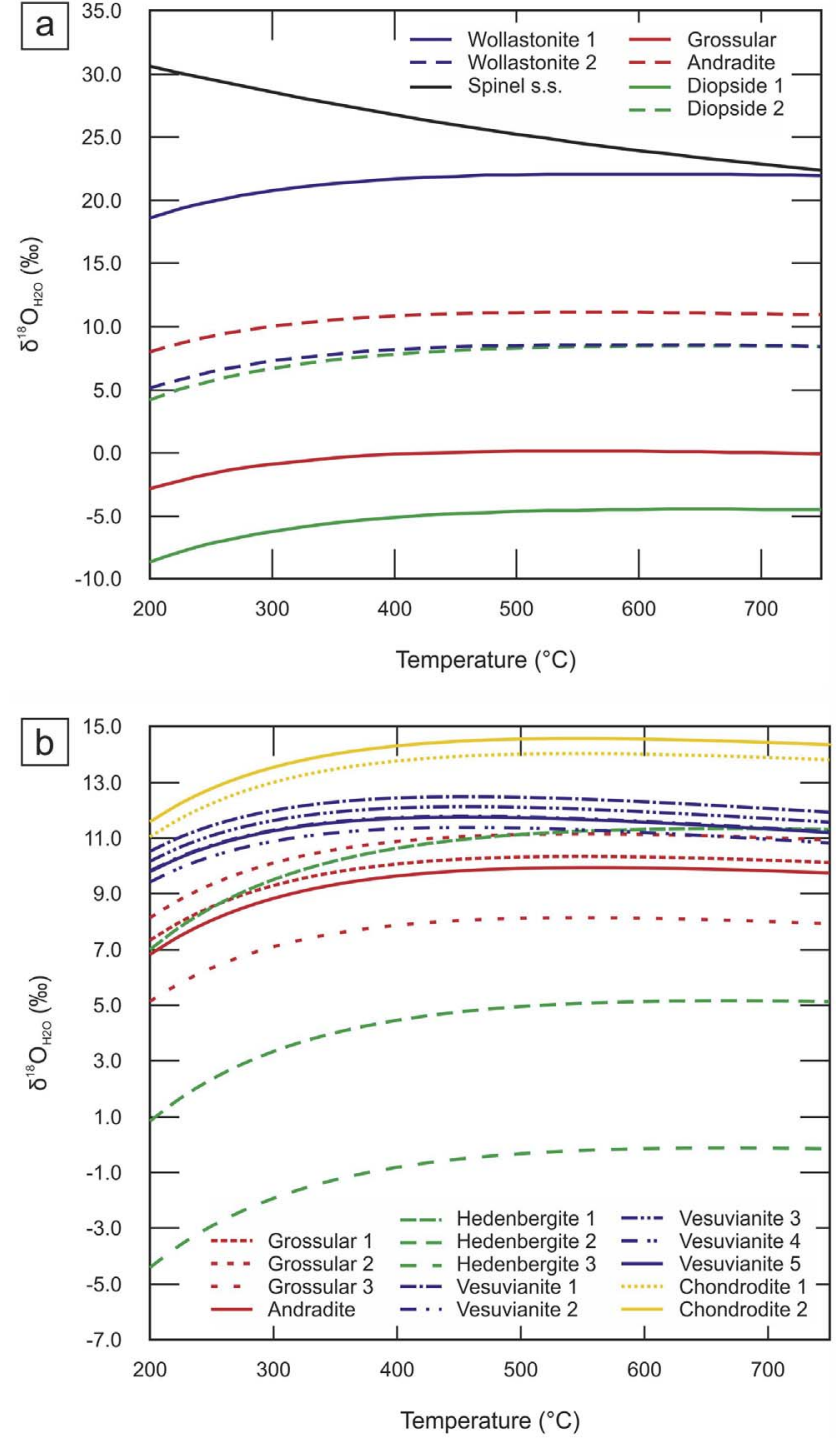

Fig. 18. Temperature dependence of oxygen between an aqueous fluid and the minerals from the Loma Marcelo skarn listed in Supplementary Material 11. The fractionation factors used are those of Zheng (1991, 1993a,b).

F-metasomatism. The Sm-Nd age of $526.8 \pm 12.0 \mathrm{Ma}$ (type 2 garnet-whole rock pair) allows us to relate this second event to the post-magmatic hydrothermal activity of the Early Cambrian alkaline magmatism (ca. 533-524 Ma; Rapela et al., 2003; Tohver et al., 2012). This magmatism is characterized by A-type granites with fluorite as a common accessory mineral and F contents of up to $2.89 \%$ (Grecco and Gregori, 1993). In addition, the titanite crystals from the calcic skarn show compositional zoning, with low F contents in the core and higher amounts in the rims. This $\mathrm{F}$ variation suggests the development of two retrogradation stages related to pre- and post-M2 events, respectively lower and higher in F. The genesis of dozyite would also be related to the retrogradation stage subsequent to the M2 event.

Grecco and Gregori (1993) identified albitization, biotitization, and fluoritization processes of post-magmatic hydrothermal origin in the Early Cambrian alkaline magmatism. According to them, albitization and biotitization would have occurred at temperatures bracketed between 400 and $500{ }^{\circ} \mathrm{C}$, whereas fluoritization occurred around at $320^{\circ} \mathrm{C}$. This last temperature may be applied to the F-metasomatism in the skarn.

Finally, the M3 event is represented by type 3 garnet (Table 1), interpreted as post-tectonic with respect to mylonitization. It was 

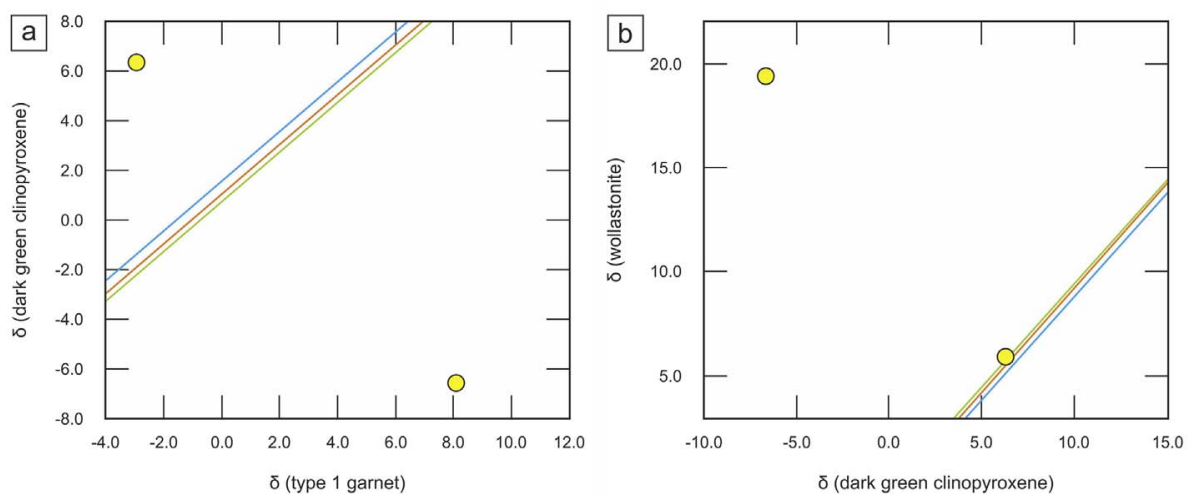

Fig. 19. Delta-delta diagrams constructed for some cogenetic mineral pairs from the Loma Marcelo skarn ("a" and "b" correspond to the M1 event and "c" and "d" to the M2 event). The yellow circles correspond to the measured values and the parallel lines are the isotherms of $300{ }^{\circ} \mathrm{C}$ (blue), $500{ }^{\circ} \mathrm{C}$ (red), and $700{ }^{\circ} \mathrm{C}$ (green). Isothermal lines were calculated after Javoy et al. (1970) with the fractionation factors of Zheng (1993a,b). (For interpretation of the references to colour in this figure legend, the reader is referred to the web version of this article.)
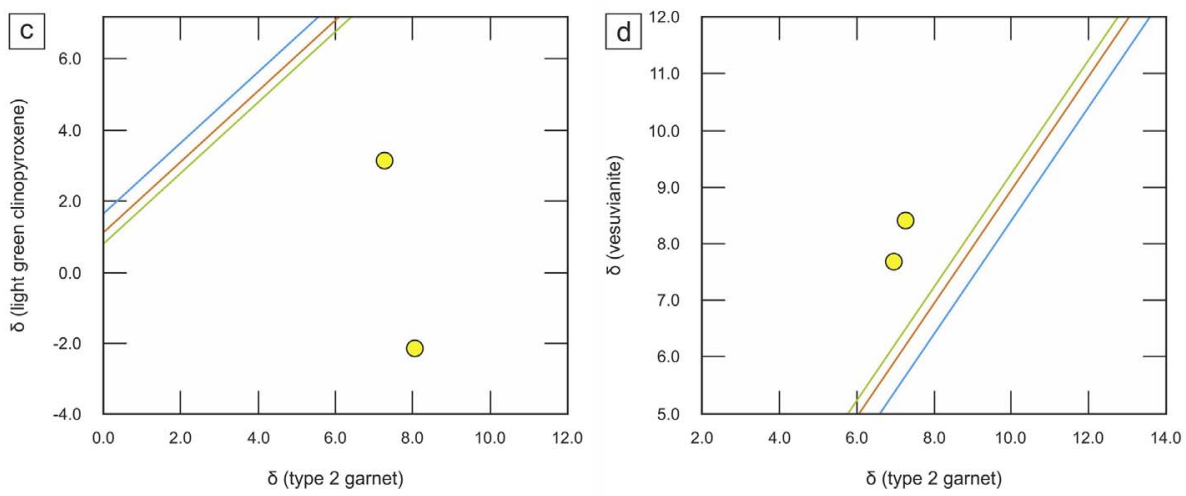

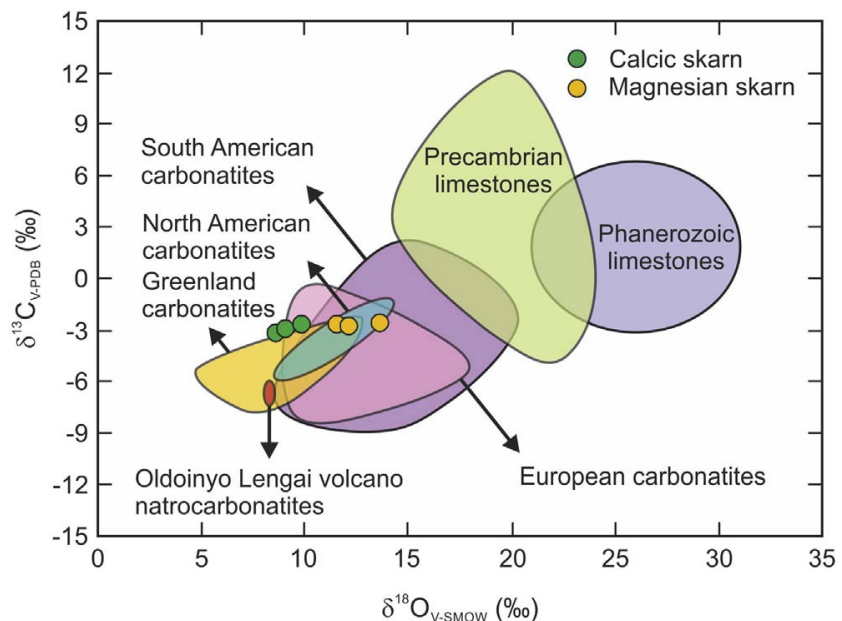

Fig. 20. Comparison of the stable isotope compositions between the Loma Marcelo skarn, limestones of different ages, and carbonatites from different continents (isotope data from Ballivián Justiniano et al. (2015), modified from Bell and Simonetti (2009)).

formed by processes of static crystallization, evidenced by the lack of deformational features. The formation of almost pure grossular and the extreme mobility of elements during the mylonitization of the basement rocks of the Sauce Chico Inlier would be related to the action of fluids with fluoride complexes that increased the mobility of $\mathrm{Al}$ and other elements. A third retrogradation process is proposed as the one responsible for the formation of epidote in the calcic skarn and serpentine in the magnesian skarn.

The regional metamorphism related to the M3 event is assigned to the Late Devonian-Early Carboniferous on the basis of a LA-ICP-MS $\mathrm{U}-\mathrm{Pb}$ lower intercept age of $353.4 \pm 6.7 \mathrm{Ma}$ determined on zircons of the skarn as well as a Rb-Sr quartz-sericite isochron age of $364.4 \pm 3.6 \mathrm{Ma}$ obtained from a quartz vein that post-tectonically cuts the already mylonitized granites. This event could be responsible for the ductile deformation evidenced in the crystalline basement and the Palaeozoic sedimentary cover. On the basis of lithofacial and structural differences between the Ventana and Pillahuincó groups, Massabie and Rossello (1984) assigned the deformation of the Ventania System to the Chanic Orogenic Phase (Late Devonian-Early Carboniferous; Turner and Méndez, 1975), in addition to the San Rafael Orogenic Phase (Early Permian). Ramos et al. (1984) related this orogeny to the collision of the Chilenia terrane with the Gondwanan margin. Tomezzoli (2012) attributed the deformation evidenced on the SW edge of Gondwana to the collision of the Patagonia and Chilenia terranes from the south and from the west, respectively; the collisions of both terranes would have begun at the same time during the Middle Devonian.

Oxygen stable isotopes in silicates and oxides from the Loma Marcelo skarn suggest extensive interaction with hydrothermal fluids of igneous, metamorphic, and possibly meteoric origin. The $\delta^{18} \mathrm{O}$ values expected in an aqueous fluid in equilibrium with the analysed minerals as temperature changes are shown in Fig. 18. In a $\delta^{18} \mathrm{O}_{\mathrm{H} 2 \mathrm{O}}$-temperature diagram, fluid values are represented by trajectories for each cogenetic mineral that should coincide at some point if the system is in equilibrium. The intersection point indicates the equilibrium temperature between the minerals and the fluid. However, as can be seen in Fig. 18, the trajectories rarely coincide, and when they do the temperatures are not geologically reasonable.

Fig. 19 shows "delta-delta" diagrams constructed from the $\delta^{18} \mathrm{O}$ results of Supplementary Material 11. The basis of this type of diagram lies in the fact that a mineral pair equilibrated at different temperatures must have values that define an isothermal line (Javoy et al., 1970); different isotherms must give rise to parallel lines. If a system originally in equilibrium at a given temperature readjusts its isotopic values as temperature changes, the analytical results should fall on the corresponding isotherm. The isotherms corresponding to three temperatures $\left(300,500\right.$, and $\left.700{ }^{\circ} \mathrm{C}\right)$ are shown in Fig. 19 and the values of mineral pairs from the same sample were projected on them. As can be observed, the analysed minerals are not in isotopic equilibrium, thereby preventing the characterization of the fluids and the determination of equilibrium temperatures (because such an 


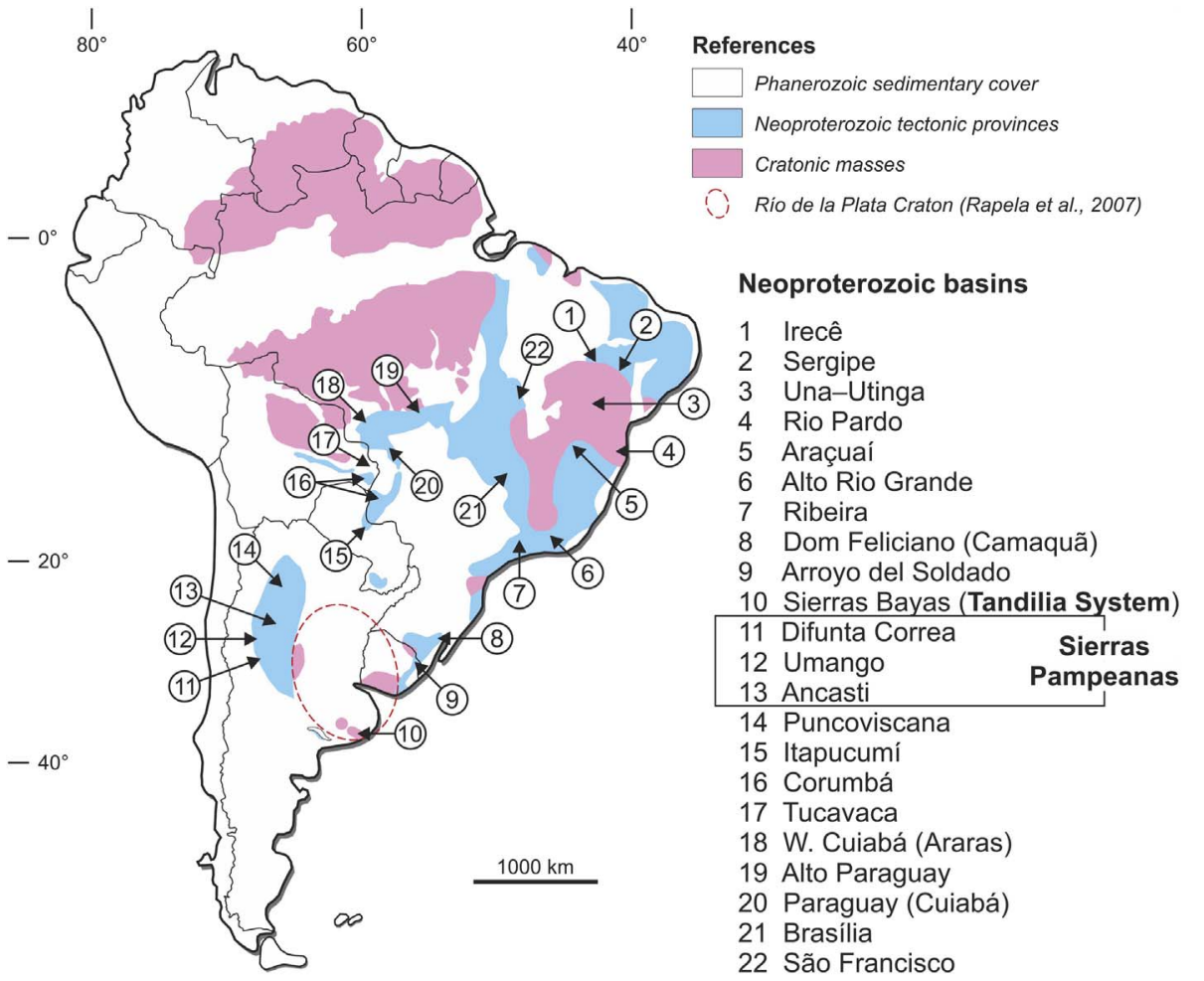

Fig. 21. Locations of the main Neoproterozoic sedimentary basins in South America (modified from Basei et al. (2010) and Misi et al. (2007)). It should be noted that Neoproterozoic carbonate rocks from Difunta Correa Formation (Galindo et al., 2004), Sierra de Umango (Varela et al., 2001), and Sierra de Ancasti (Murra et al., 2011) are not autochthonous to Gondwana; they overlay the allochthonous Grenvillian basement of Mesoproterozoic terranes, which collided with Gondwana in Ordovician times. (See above-mentioned references for further information.) equilibrium does not exist). Thus, it is evident that the fluid activity in the basement rocks of the Sauce Chico Inlier was intense. This fluid activity could have been responsible for an effective distribution of heat and weakening of the materials, contributing to the ductile shearing observed in the crystalline basement of the Ventania System (Sellés-Martínez, 2001).

\subsection{Origin of the carbonate protoliths of the Loma Marcelo skarn}

Skarns are rocks formed by the interaction of carbonate and silicate systems in mutual contact (Zharikov et al., 2011). They are formed from carbonate protoliths of diverse nature, like limestones, dolostones, marls, hydrothermal carbonates, carbonatites, and marbles. Regardless of the composition of the protolith, what defines a rock as skarn is the mineralogy resulting from metasomatic alteration, which includes numerous calc-silicate or magnesian minerals, depending on the chemical composition of the protolith (Einaudi et al., 1981; Meinert, 1992). Regarding the geological environment, skarns can be formed during regional, dynamic, or contact metamorphism through metasomatic processes involving fluids of magmatic, metamorphic, meteoric, and/or marine origin (Meinert et al., 2005).

The possibility that the Loma Marcelo skarn derived from a carbonatitic protolith intruded into the Sauce Chico Inlier granites was first considered due to the elongated and dyke-like arrangement of the skarn boudins, the presence of certain mineral associations and textures, and the regional petrotectonic context during the Early to Middle Cambrian (Ballivián Justiniano et al., 2015). However, the low total trace element contents and the marked negative Eu anomalies present in the Loma Marcelo skarn are features typical of carbonate rocks of sedimentary origin and their metamorphic equivalents (e.g. marbles). Sr is the only element that is typically low in sedimentary and metasedimentary carbonates $(<0.1 \%$ SrO; Morse and Mackenzie, 1990) and high in carbonatites and metacarbonatites ( $>0.5 \% \mathrm{SrO}$; Woolley and Kempe, 1989; Ahijado et al., 2005). Carbonatites frequently retain their igneous compositional features even after hightemperature metamorphic events accompanied by hydrothermal fluid circulation (Casillas et al., 2011). The average content of SrO in the Loma Marcelo skarn is $0.03 \%$, which is similar to the average upper crust content of $0.04 \%$ (Taylor and McLennan, 1985, 1995). In addition, the occurrence of scapolite, calcic plagioclase, and spinel sensu stricto - Al-rich minerals - is usually an accurate indication of the sedimentary origin of the protoliths (Le Bas et al., 2002).

Stable isotope determinations of carbon $\left(\delta^{13} \mathrm{C}_{\mathrm{V}-\mathrm{PDB}}=-2.6\right.$ / $-3.2 \% 0)$ and oxygen $\left(\delta^{18} \mathrm{O}_{\mathrm{V} \text {-SMow }}=+8.6 /+13.6 \%\right.$ ) in carbonate minerals show important decreases in ${ }^{13} \mathrm{C}$ and ${ }^{18} \mathrm{O}$ relative to values that are frequent in limestones and marbles (Ballivián Justiniano et al., 2015) (Fig. 20). This isotopic signature is also consistent with that observed in many contact aureoles and in most skarns around the world formed from limestones or metalimestones due to water-rock interaction processes (e.g. Bowman, 1998).

The prismatic and subrounded shapes of the zircon grains, interpreted as detrital in origin, indicate minor transport from the source region. The age of $648 \pm 21 \mathrm{Ma}$ is interpreted as the crystallization age of the analysed zircon, providing the maximum sedimentation age for the calcic protolith of the Loma Marcelo skarn. The minimum sedimentation age is provided by the crystallization age of the S-type granite that includes the skarn (ca. $607 \mathrm{Ma}$; Rapela et al., 2003). In consequence, the sedimentation of the calcic skarn protolith should have occurred between the Late Cryogenian (post-648 Ma) and the Early Ediacaran (pre-607 Ma). In this regard, it is noteworthy that Neoproterozoic limestones are key geological features widely distributed along the Brasiliano-Pan-African orogenic belts that amalgamated old cratonic cores during the assembly of West Gondwana.

Neoproterozoic sedimentary successions were largely accumulated during extensional events associated with the breakup of Rodinia in South America (Misi et al., 2007). These units consist of carbonate and siliciclastic rocks deposited in epicontinental seaways and shallow marine environments on passive cratonic margins. During the Brasiliano-Pan-African orogeny, the Neoproterozoic sedimentary sequences were deformed into mobile belts surrounding the cratons. The main South American basins of Neoproterozoic-Early Palaeozoic 


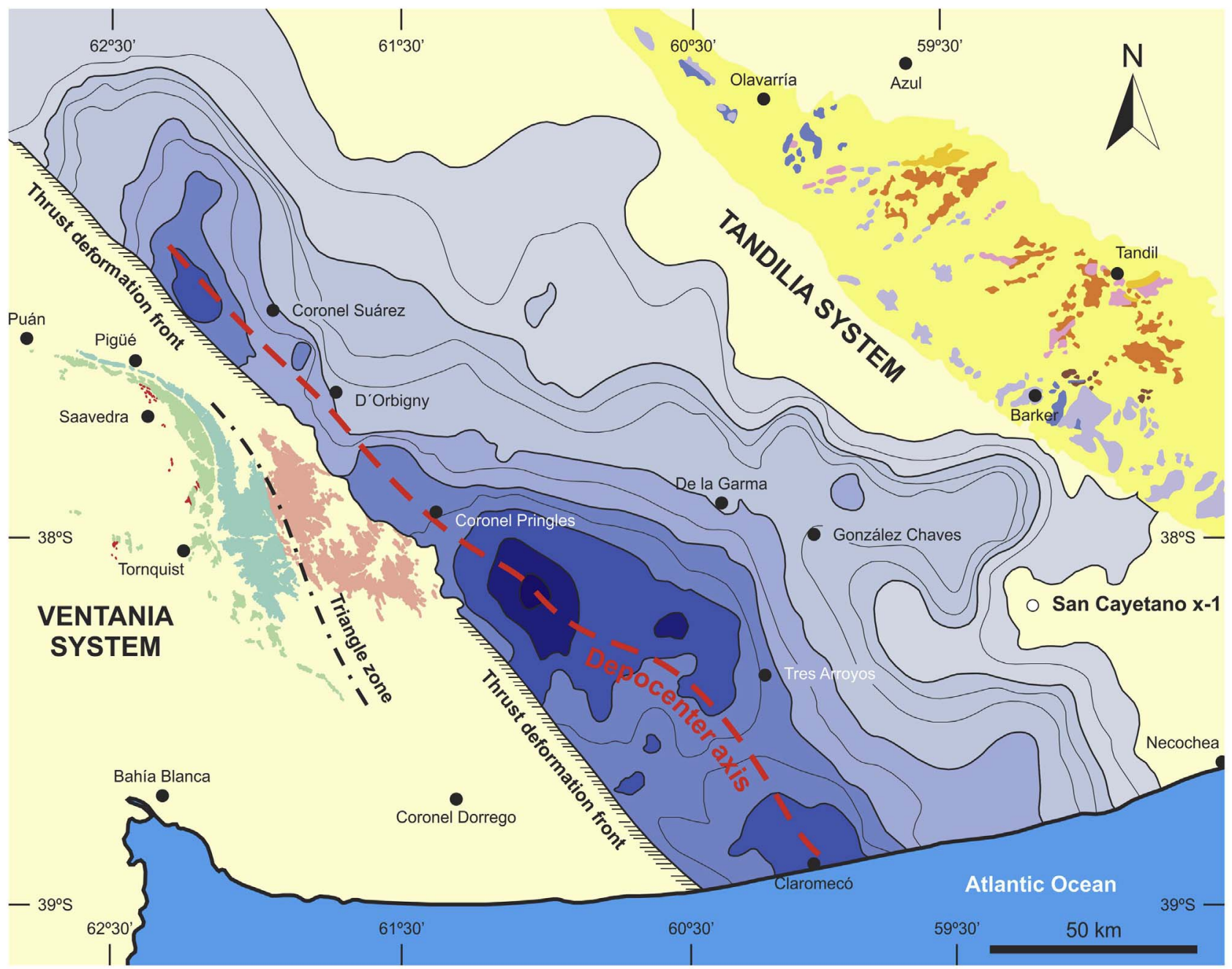

\section{References}

\begin{tabular}{|c|}
\hline Quaternary sedimentary cover \\
\hline Neogene sedimentary cover \\
\hline Pillahuincó Group (Carboniferous-Early Permian) \\
\hline Ventana Group (Silurian-Devonian) \\
\hline Curamalal Group (Late Cambrian-Ordovician) \\
\hline $\begin{array}{l}\text { Ventania System crystalline basement } \\
\text { (Neoproterozoic-Middle Cambrian) }\end{array}$ \\
\hline
\end{tabular}

Cerro Negro and Balcarce formations (Cambrian-Ordovician)

Sierras Bayas Group (Neoproterozoic)

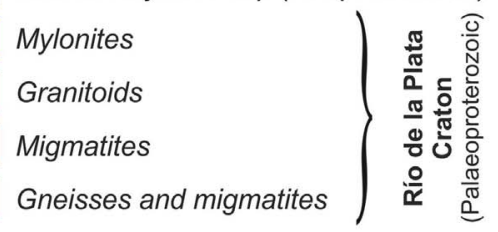

\section{Gravimetric map of the Claromecó Basin}

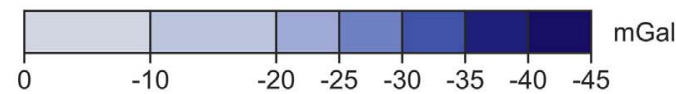

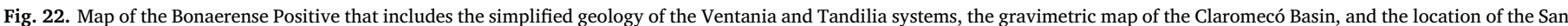
Cayetano $\mathrm{x}-1$ exploratory well (based on Ramos and Kostadinoff (2005)).

age are shown in Fig. 21, including the Sierras Bayas Basin (Tandilia System) in Argentina. The carbonate rocks of the Puncoviscana Formation in Northwest Argentina can also be mentioned (Aceñolaza and Aceñolaza, 2005). The Neoproterozoic carbonate rocks that overlay the Río de la Plata Craton, among others from the Atlantic margin of South America, have their African counterparts in the Saldania, Gariep, Damara, Kaoko, and West Congo belts (Frimmel, 2009, and references therein).

The carbonate sequences of the Tandilia System (Fig. 22) are represented by dolostones of Villa Mónica Formation and limestones of Loma Negra Formation, both belonging to the Sierras Bayas Group
(Dalla Salda and Iñíguez Rodríguez, 1979; Poiré, 1993), underlying the siliciclastic sedimentary rocks of the Cerro Negro and Balcarce formations (Amos et al., 1972; Dalla Salda and Iñíguez Rodríguez, 1979). The Villa Mónica Formation has a maximum thickness of $70 \mathrm{~m}$ and is composed of a lower quartz-arkosic facies and upper dolomitic and pelitic facies (Poiré and Spalletti, 2005). The dolomitic sequence consists of 36 to $52 \mathrm{~m}$ of stromatolitic and laminated yellowish dolostones with shales and marls and small mudstone lenses. For its part, the Loma Negra Formation consists of $40 \mathrm{~m}$ of reddish and black mudstones (Poiré and Spalletti, 2005). Based on C, O, and Sr isotopic data, Gómez Peral et al. (2007) assigned the ages of the carbonate 


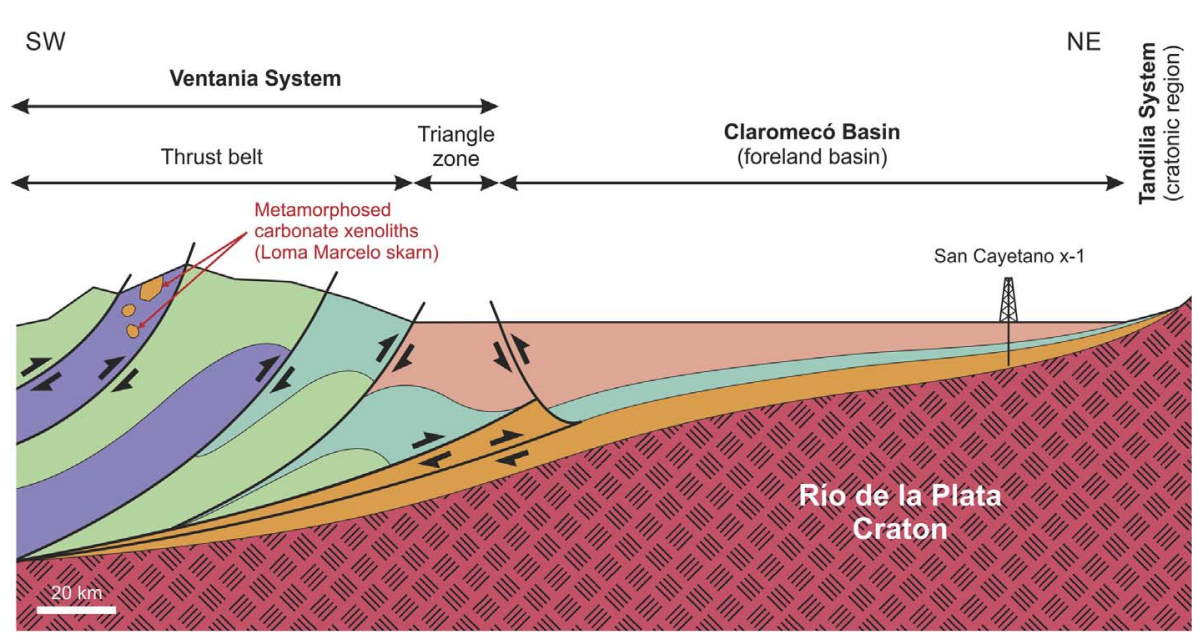

Fig. 23. Structural cross-section scheme of the Bonaerense Positive, from the Tandilia System to the Ventania System across the Claromecó Basin (based on Ramos (1999), Tomezzoli and Cristallini (2004), and Ramos and Kostadinoff (2005)). The vertical scale is very exaggerated and the Cenozoic sedimentary cover has been omitted.

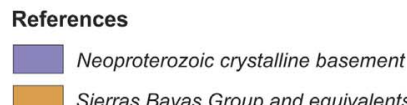

Pillahuincó Group and equivalents

Ventana Group and equivalents

Curamalal Group and equivalents

sequences of the Villa Mónica and Loma Negra formations to the intervals of $c a$. 800-720 Ma and ca. 590-580 Ma, respectively.

Several wells were drilled in the Claromecó Basin located between the Tandilia and Ventania systems (Kostadinoff and Font de Affolter, 1982; Ramos, 1984) (Fig. 22), and rocks similar to those of the Sierras Bayas Group, Cerro Negro, and Balcarce formations of the Tandilia System and/or the Pillahuincó Group of the Ventania System were identified in these wells (Lesta and Sylwan, 2005). The stratigraphic units of the Claromecó Basin, which are comparable to the Neoproterozoic-Eopalaeozoic sedimentary sequence of the Tandilia System, are wedge-shaped, with a marked decrease in thickness towards the northeast flank of the basin and an important increase of thickness towards the southeast. In the exploratory well BA.SC. $\mathrm{x}-1$ (San Cayetano), with a final depth of $2045 \mathrm{~m}$ under the wellhead, Bridas Corp. drilled $153 \mathrm{~m}$ of grey dolostones with intercalations of sandstones correlated to the Villa Mónica Formation and $36 \mathrm{~m}$ of grey limestones and pelites correlated with the Loma Negra Formation. Although the crystalline basement was not reached, it would be less than $100 \mathrm{~m}$ below the bottom of the well (Lesta and Sylwan, 2005).

The integration of surface and subsurface information of the Tandilia and Ventania systems and the Claromecó Basin allowed several authors (Ramos, 1984, 1999, 2008; Ramos and Kostadinoff, 2005; Lesta and Sylwan, 2005; Ramos et al., 2014) to postulate the continuity of the crystalline basement and the Neoproterozoic-Eopalaeozoic sedimentary cover of the Tandilia System in the underground of the Claromecó Basin and Ventania System (Fig. 23). In agreement with this interpretation, the Loma Marcelo skarn would constitute the surficial expression of Neoproterozoic carbonate rocks (post-648 Ma and pre-607 Ma) existing underneath the Ventania System. Nd model ages for the calcic skarn indicate that precursor rocks were extracted from the mantle at 2.52-2.46 Ga (Supplementary Material 10), in good agreement with mantle-extraction ages for basement units of the Olavarría city area in the Tandilia System $\left(\mathrm{T}_{\mathrm{DM}}=2.62 \pm 0.08 \mathrm{Ga}\right.$; Pankhurst et al., 2003).

\section{Conclusions}

The Loma Marcelo skarn was formed from carbonate xenoliths of sedimentary origin incorporated during the intrusion of the Sauce Chico Inlier granite. The generation of calcic and magnesian skarns was controlled by the different compositions of their carbonate protoliths. The sedimentary nature of the protoliths of both types of skarns is reflected in their chemical and mineralogical compositions. These protoliths would be genetically related to the Neoproterozoic carbonate rocks recorded in the Brasiliano-Pan-African orogenic belts of Eastern South America and Western Africa. The LA-ICP-MS U-Pb age of $648 \pm 21$ Ma determined in a single zircon of the skarn supports this assumption. The source area for the Loma Marcelo skarn protoliths could be the Neoproterozoic carbonate rocks from the underground of the Claromecó Basin.

The skarn is the result of the following three different metasomatic events (M) linked to fluids of igneous and metamorphic origin: M1) intrusion of the Neoproterozoic S-type granite; M2) Early Cambrian alkaline magmatism and its post-magmatic hydrothermal activity (e.g. Cerro Colorado and Estancia Agua Blanca granites); and M3) regional metamorphism of the Late Devonian-Early Carboniferous.

The Neoproterozoic age of the M1 event is given by the isotopic dating in zircons of the Sauce Chico Inlier granites that contain the Loma Marcelo skarn. Regarding the M2 event, the recognition of high-F minerals in the skarn (e.g. vesuvianite, chondrodite) and the Sm-Nd isochron age of $526.8 \pm 12.0 \mathrm{Ma}$ allowed the strong F-metasomatism to be associated with the Early Cambrian magmatism. The possible age of the M3 event is supported by the LA-ICP-MS U-Pb lower intercept age of $353.4 \pm 6.7$ Ma determined on zircons of the calcic skarn and by a $\mathrm{Rb}-\mathrm{Sr}$ isochron age of $364.4 \pm 3.6 \mathrm{Ma}$ obtained on a vein which post-tectonically cuts the already deformed rocks.

\section{Acknowledgements}

This work constitutes part of the doctoral thesis of the first author supported by a student grant awarded by the Consejo Nacional de Investigaciones Científicas y Técnicas (CONICET) of Argentina. We would like to thank Pablo D. González (Universidad Nacional de Río Negro, Argentina) for helping with the U-Pb dating. We also thank Agustín Martín-Izard (Universidad de Oviedo, Spain) and Fernando Colombo (Universidad Nacional de Córdoba, Argentina) for helping with the electron microprobe. This study was supported by research grants awarded by the Comisión de Investigaciones Científicas de la Provincia de Buenos Aires (CIC) and the Universidad Nacional de La Plata (UNLP). We warmly acknowledge the reviews by P.D. González and an anonymous reviewer, which improved the original manuscript considerably. 


\section{Appendix A. Supplementary data}

Supplementary data associated with this article can be found, in the online version, at http://dx.doi.org/10.1016/j.precamres.2017.09.021.

\section{References}

Aceñolaza, F., Aceñolaza, G., 2005. La Formación Puncoviscana y unidades estratigráficas vinculadas en el Neoproterozoico-Cámbrico Temprano del Noroeste Argentino. Lat. Am. J. Sedimentol. Basin Anal. 12, 65-87.

Ahijado, A., Casillas, R., Nagy, G., Fernández, C., 2005. Sr-rich minerals in a carbonatite skarn, Fuerteventura, Canary Islands (Spain). Mineral. Petrol. 84, 107-127.

Amos, A., Quartino, B., Zardini, R., 1972. El "Grupo La Tinta" (Provincia de Buenos Aires). Paleozoico y Precámbrico? In: $25^{\circ}$ Congresso Brasileiro de Geologia, São Paulo, Atas, pp. 211-221.

Andreis, R.R., Iñíguez, A.M., Lluch, J.L., Rodríguez, S., 1989. Cuenca Paleozoica de Ventania, Sierras Australes, Provincia de Buenos Aires. In: Chebli, G.A., Spalletti, L.A. (Eds.), Cuencas Sedimentarias Argentinas. Instituto Superior de Correlación Geológica, Serie Correlación Geológica 6, San Miguel de Tucumán, Argentina, pp. 265-298.

Azcuy, C.L., Caminos, R., 1987. Diastrofismo. In: Archangelsky, S. (Ed.), El Sistema Carbonífero en la República Argentina. Academia Nacional de Ciencias, Córdoba, Argentina, pp. 239-251.

Ballivián Justiniano, C.A., 2016. Geología y aspectos estructurales del área Cerro Pan de Azúcar-Cerro del Corral. Procesos petrogenéticos/geoquímica del skarn Loma Marcelo, Sierras Australes de Buenos Aires (Ph.D. thesis). Universidad Nacional de La Plata.

Ballivián Justiniano, C.A., Lanfranchini, M.E., Recio Hernández, C., de Barrio, R.E., 2015. Procesos metamórficos y metasomáticos en el skarn Loma Marcelo, basamento neoproterozoico de las Sierras Australes de la Provincia de Buenos Aires. Rev. Asoc. Geol. Argent. 72, 404-418.

Barker, F., 1979. Trondhjemites: definition, environment and hypothesis of origin. In: Barker, F. (Ed.), Trondhjemites, Dacites and Related Rocks. Elsevier, Amsterdam, pp. $1-12$.

Basei, M.A.S., Neves, B.B.B., Siga Junior, O., Babinski, M., Pimentel, M.M., Tassinari, C.C.G., Hollanda, M.H.B., Nutman, A., Cordani, U.G., 2010. Contribution of SHRIMP $\mathrm{U}-\mathrm{Pb}$ zircon geochronology to unravelling the evolution of Brazilian Neoproterozoic fold belts. Precambr. Res. 183, 112-144.

Bell, K., Simonetti, A., 2009. Source of parental melts to carbonatites-critical isotopic constraints. Mineral. Petrol. 98, 77-89.

Borthwick, J., Harmon, R.S., 1982. A note regarding $\mathrm{ClF}_{3}$ as an alternative to $\mathrm{BrF}_{5}$ for oxygen isotope analysis. Geochim. Cosmochim. Acta 46, 1665-1668.

Lentz, J.R., 1998. Stable-isotope systematics of Skarns. In: Bowman, D.R. (Ed.), Mineralized Intrusion-Related Skarn Systems. Short Course vol. 26. Mineralogical Association of Canada, Quebec, pp. 99-145.

Bucher, K., Grapes, R., 2011. Petrogenesis of Metamorphic Rocks. Springer, Berlin.

Buggisch, W., 1987. Stratigraphy and very low-grade metamorphism of the Sierras Australes de la Provincia de Buenos Aires (Argentina) and implications in Gondwana correlation. Zentralbatt für Geologie Paläontologie Teil I (7/8), 819-837.

Casillas, R., Demény, A., Nagy, G., Ahijado, A., Fernández, C., 2011. Metacarbonatites in the Basal Complex of Fuerteventura (Canary Islands). The role of fluid/rock interactions during contact metamorphism and anatexis. Lithos 125, 503-520.

Chemale Jr., F., Scheepers, R., Gresse, P.G., Van Schmus, W.R., 2011. Geochronology and sources of late Neoproterozoic to Cambrian granites of the Saldania Belt. Int. J. Earth Sci. 100, 431-444.

Cingolani, C.A., 2011. The Tandilia System of Argentina as a southern extension of the Río de la Plata craton: an overview. Int. J. Earth Sci. 100, 221-242.

Cingolani, C.A., Varela, R., 1973. Examen geocronológico por el método RubidioEstroncio de las rocas ígneas de las Sierras Australes Bonaerenses. In: $5^{\circ}$ Congreso Geológico Argentino, Buenos Aires, Actas, vol. 1, pp. 349-371.

Clayton, R.N., Mayeda, T.K., 1963. The use of bromine pentafluoride in the extraction of oxygen from oxides and silicates for isotopic analysis. Geochim. Cosmochim. Acta 27, $43-52$.

Cobbold, P.R., Massabie, A.C., Rossello, E.A., 1986. Hercynian wrenching and thrusting in the Sierras Australes Foldbelt, Argentina. Hercynica 2, 135-148.

Cobbold, P.R., Gapais, D., Rossello, E.A., 1991. Partitioning of transpressive motions within a sigmoidal foldbelt: the Variscan Sierras Australes, Argentina. J. Struct. Geol. 13, 743-758.

Cordani, U.G., Jacobsohn, T., Sato, K., Petronilho, L., Ferreira, T.C.O., 2005. On Samarium-Neodymium isochron dating of garnet and the role of inclusions. In: European Geosciences Union General Assembly, Vienna, Geophysical Research Abstracts, vol. 7, SRef-ID: 1607-7962/gra/EGU05-A-05736.

Cordani, U.G., Pimentel, M.M., Ganade de Araújo, C.E., Fuck, R.A., 2013. The significance of the Transbrasiliano-Kandi tectonic corridor for the amalgamation of West Gondwana. Braz. J. Geol. 43, 583-597.

Cucchi, R.J., 1966. Petrofábrica del conglomerado de la Formación La Lola, Sierras Australes de la provincia de Buenos Aires. Rev. Asoc. Geol. Argent. 21, 71-106.

Cuerda, A.J., Cingolani, C.A., Barranquero, H.R., 1975. Estratigrafía del basamento precámbrico en la comarca de los cerros Pan de Azúcar-del Corral, Sierras Australes (Provincia de Buenos Aires). In: $2^{\circ}$ Congreso Iberoamericano de Geología Económica, Buenos Aires, Actas, vol. 1, pp. 57-63.

Dalla Salda, L., Iñíguez Rodríguez, A.M., 1979. La Tinta, Precámbrico y Paleozoico de Buenos Aires. In: $7^{\circ}$ Congreso Geológico Argentino, Buenos Aires, Actas, vol. 1, pp 539-550. de Almeida, F.F.M., 1971. Geochronological division of the Precambrian of South America. Braz. J. Geol. 1, 13-21.

Delpino, S.H., 1993. Mecanismos de deformación y transformaciones mineralógicas como indicadores del régimen de deformación operante sobre las rocas del basamento del faldeo occidental del cerro del Corral, Sierras Australes de Buenos Aires. In: $12^{\circ}$ Congreso Geológico Argentino y $2^{\circ}$ Congreso de Exploración de Hidrocarburos, Buenos Aires, Actas, vol. 3, pp. 21-31.

Delpino, S.H., Dimieri, L.V., 1992. Análisis de la deformación sobre las rocas del basamento aflorantes en el faldeo occidental del cerro del Corral, Sierras Australes Bonaerenses. In: $7^{\circ}$ Reunión de Microtectónica, Bahía Blanca, Actas, pp. 53-61.

Du Toit, A.L., 1927. A Geological Comparison of South America with South Africa. With a paleontological contribution by F. R. Cowper Reed. vol. 381. Carnegie Institution Publication, pp. 1-157.

Einaudi, M.T., Meinert, L.D., Newberry, R.J., 1981. Skarn Deposits. In: Skinner, B.J. (Ed.), Economic Geology, $75^{\text {th }}$ Anniversary Volume, Littleton, pp. 317-391.

Fitzgerald, S., Rheingold, A.L., Leavens, P.B., 1986. Crystal structure of a Cu-bearing vesuvianite. Am. Mineral. 71, 1011-1014.

Frimmel, H.E., 2009. Trace element distribution in Neoproterozoic carbonates as palaeoenvironmental indicator. Chem. Geol. 258, 338-353.

Galindo, C., Casquet, C., Rapela, C., Pankhurst, R., Baldo, E., Saavedra, J., 2004. Sr, C and $\mathrm{O}$ isotope geochemistry and stratigraphy of Precambrian and lower Paleozoic carbonate sequences from the Western Sierras Pampeanas of Argentina: tectonic implications. Precambr. Res. 131, 55-71.

Gioia, S.M.C.L., Pimentel, M.M., 2000. The Sm-Nd isotopic method in the Geochronology Laboratory of the University of Brasília. An. Acad. Bras. Cienc. 72, 219-245.

Gómez Peral, L.E., Poiré, D.G., Strauss, H., Zimmermann, U., 2007. Chemostratigraphy and diagenetic constraints on Neoproterozoic carbonate successions from the Sierras Bayas Group, Tandilia System, Argentina. Chem. Geol. 237, 109-128.

González, P.D., Páez, G.N., Cervera, F.M., Iribarne, M., 2004. Texturas relícticas en las metaignimbritas neoproterozoicas del basamento del cerro del Corral, Sierras Australes de Buenos Aires. Rev. Asoc. Geol. Argent. 59, 103-112.

Grecco, L.E., Gregori, D.A., 1993. Estudio geoquímico de los intrusivos graníticos cerros Colorados y Aguas Blancas, Sierras Australes, Provincia de Buenos Aires, Argentina. In: $12^{\circ}$ Congreso Geológico Argentino y $2^{\circ}$ Congreso de Exploración de Hidrocarburos, Buenos Aires, Actas, vol. 4, pp. 81-89.

Grecco, L.E., Delpino, S.H., Gregori, D.A., Dimieri, L.V., 2000. Evaluación de la movilidad de elementos mayoritarios y traza durante la milonitización de rocas del basamento de las Sierras Australes de Buenos Aires. Rev. Asoc. Geol. Argent. 55, 352-362.

Gregori, D.A., López, V.L., Grecco, L.E., 2005. A late proterozoic-early Paleozoic magmatic cycle in Sierra de la Ventana, Argentina. J. S. Am. Earth Sci. 19, 155-171.

Griffin, W.L., Brueckner, H.K., 1980. Caledonian Sm-Nd ages and a crustal origin for Norwegian eclogites. Nature 285, 319-320.

Harrington, H.J., 1947. Explicación de las Hojas Geológicas 33m y 34m, Sierras de Curamalal y de la Ventana, Provincia de Buenos Aires. Dirección de Minas y Geología, Boletín 61, Buenos Aires.

Harrington, H.J., 1970. Las Sierras Australes de Buenos Aires, República Argentina: cadena aulacogénica. Rev. Asoc. Geol. Argent. 25, 151-181.

Harrington, H.J., 1972. Sierras Australes de Buenos Aires. In: Leanza, A.F. (Ed.), Geología Regional Argentina. Academia Nacional de Ciencias, Córdoba, Argentina, pp. 395-405.

Hartnady, C., Joubert, P., Stowe, C., 1985. Proterozoic crustal evolution in Southwestern Africa. Episodes 8, 236-244.

Iñíguez, A.M., Andreis, R.R., Zalba, P.E., 1988. Eventos piroclásticos en la Formación Tunas (Pérmico), Sierras Australes, provincia de Buenos Aires, República Argentina. In: $2^{\circ}$ Jornadas Geológicas Bonaerenses, Bahía Blanca, Actas, pp. 383-395.

Irvine, T.N., Baragar, W.R.A., 1971. A guide to the chemical classification of the common volcanic rocks. Can. J. Earth Sci. 8, 523-548.

Japas, M.S., 1987. Caracterización geométrico-estructural del Grupo Pillahuincó. II. Formación Sauce Grande. Perfil del Cordón Mambacher y Sierra de las Tunas occidental, Sierras Australes de Buenos Aires. Anales de la Academia Nacional de Ciencias Exactas, Físicas y Naturales (Buenos Aires) 39, 125-144.

Javoy, M., Fourcade, S., Allegre, C.J., 1970. Graphical method for examination of ${ }^{18} \mathrm{O} /{ }^{16} \mathrm{O}$ fractionations in silicate rocks. Earth Planet. Sci. Lett. 10, 12-16.

Kawashita, K., 1972. O método Rb-Sr em rochas sedimentares. Aplicação para as bacias do Paraná e Amazonas (Ph.D. thesis). Universidade de São Paulo.

Keidel, J., 1916. La Geología de las Sierras de la Provincia de Buenos Aires y sus Relaciones con las Montañas de Sud África y los Andes, República Argentina. An. Min. Agric. Nac. (Argentina) 11, 1-78.

Kilmurray, J.O., 1968. Petrología de las rocas cataclásticas y el skarn del anticlinal del Cerro Pan de Azúcar (Partido de Saavedra, Provincia de Buenos Aires). In: $3^{\circ}$ Jornadas Geológicas Argentinas, Buenos Aires, Actas, vol. 3, pp. 217-238.

Kilmurray, J.O., 1975. Las Sierras Australes de la Provincia de Buenos Aires. Las fases de deformación y nueva interpretación estratigráfica. Rev. Asoc. Geol. Argent. 30, 331-348.

Korhonen, F.J., Saito, S., Brown, M., Siddoway, C.S., Day, J.M.D., 2010. Multiple generations of granite in the Fosdick Mountains, Marie Byrd Land, West Antarctica: implications for polyphase intracrustal differentiation in a continental margin setting. J. Petrol. 51, 627-670.

Kostadinoff, J., Font de Affolter, G., 1982. Cuenca Interserrana Bonaerense, Argentina. In: $5^{\circ}$ Congreso Latinoamericano de Geología, Buenos Aires, Actas, vol. 4, pp. 105-121.

Le Bas, M.J., Subbarao, K.V., Walsh, J.N., 2002. Metacarbonatite or marble? - The case of the carbonate, pyroxenite, calcite-apatite rock complex at Borra, Eastern Ghats, India. J. Asian Earth Sci. 20, 127-140.

Lesta, P., Sylwan, C., 2005. Cuenca de Claromecó. In: Chebli, G.A., Cortiñas, J.S., Spalletti, L.A., Legarreta, L., Vallejo, E.L. (Eds.), Frontera Exploratoria de la Argentina. $6^{\circ}$ Congreso de Exploración y Desarrollo de Hidrocarburos, Buenos Aires, 
Argentina, pp. 217-231.

Llambías, E.J., Prozzi, C.R., 1975. Ventania. In: $6^{\circ}$ Congreso Geológico Argentino, Buenos Aires, Relatorio, pp. 79-101.

López-Gamundí, O.R., Conaghan, P.J., Rossello, E.A., Cobbold, P.R., 1995. The Tunas Formation (Permian) in the Sierras Australes Foldbelt, east central Argentina: evidence for syntectonic sedimentation in a foreland basin. J. S. Am. Earth Sci. 8, $129-142$.

Ludwig, K.R., 2008. User's Manual for Isoplot 3.7. A Geochronological Toolkit for Microsoft Excel. Berkeley Geochronology Center Special Publication 4, Berkeley.

Manning, G., 1975. Charge-transfer processes and the origin of colour and pleochroism of some Ti-rich vesuvianites. Can. Mineral. 13, 110-116.

Massabie, A., Rossello, E., 1984. La discordancia pre-Formación Sauce Grande y su entorno estratigráfico, Sierras Australes de la Provincia de Buenos Aires, Argentina. In: $9^{\circ}$ Congreso Geológico Argentino, Buenos Aires, Actas, vol. 1, pp. 337-352.

McDonough, W.F., Sun, S.-S., 1995. The composition of the earth. Chem. Geol. 120, 223-253.

Meinert, L.D., 1992. Skarns and Skarn deposits. Geosci. Can. 19, 145-162.

Meinert, L.D., Dipple, G.M., Nicolescu, S., 2005. World Skarn Deposits. In: Hedenquist, J. W., Thompson, J.F.H., Goldfarb, R.J., Richards, J.P. (Eds.), Economic Geology, $100^{\text {th }}$ Anniversary Volume, Littleton, pp. 299-336.

Misi, A., Kaufman, A.J., Veizer, J., Powis, K., Azmy, K., Boggiani, P.C., Gaucher, C., Teixeira, J.B.G., Sanches, A.L., Iyer, S.S.S., 2007. Chemostratigraphic correlation of Neoproterozoic successions in South America. Chem. Geol. 237, 143-167.

Morse, J.W., Mackenzie, F.T., 1990. Geochemistry of Sedimentary Carbonates. Elsevier, Amsterdam.

Murra, J.A., Baldo, E.G., Galindo, C., Casquet, C., Pankhurst, R.J., Rapela, C.W., Dahlquist, J., 2011. Sr, C and O isotope composition of marbles from the Sierra de Ancasti, Eastern Sierras Pampeanas, Argentina: age and constraints for the Neoproterozoic-Lower Paleozoic evolution of the proto-Gondwana margin. Geol. Acta 9, 79-92.

Pángaro, F., Ramos, V.A., 2012. Paleozoic crustal blocks of onshore and offshore central Argentina: new pieces of the southwestern Gondwana collage and their role in the accretion of Patagonia and the evolution of Mesozoic south Atlantic sedimentary basins. Mar. Pet. Geol. 37, 162-183.

Pángaro, F., Ramos, V.A., Pazos, P.J., 2016. The Hesperides basin: a continental-scale upper Palaeozoic to Triassic basin in southern Gondwana. Basin Res. 28, 685-711.

Pankhurst, R.J., Ramos, A., Linares, E., 2003. Antiquity of the Río de la Plata craton in Tandilia, southern Buenos Aires province, Argentina. J. S. Am. Earth Sci. 16, 5-13.

Pearce, J.A., Harris, N.B.W., Tindle, A.G., 1984. Trace element discrimination diagrams for the tectonic interpretation of granitic rocks. J. Petrol. 25, 956-983.

Poiré, D., 1993. Estratigrafía del Precámbrico sedimentario de Olavarria, Sierras Bayas, Provincia de Buenos Aires. Argentina. In: $12^{\circ}$ Congreso Geológico Argentino y $2^{\circ}$ Congreso de Exploración de Hidrocarburos, Buenos Aires, Actas, vol. 2, pp. 1-11.

Poiré, D.G., Spalletti, L.A., 2005. La cubierta sedimentaria precámbrica-paleozoica inferior del Sistema de Tandilia. In: de Barrio, R.E., Etcheverry, R.O., Caballé, M.F., Llambías, E. (Eds.), Geología y Recursos Minerales de la Provincia de Buenos Aires. Relatorio del $16^{\circ}$ Congreso Geológico Argentino, Buenos Aires, Argentina, pp. 51-68.

Ramos, V.A., 1984. Patagonia: ¿un continente Paleozoico a la deriva? In: $9^{\circ}$ Congreso Geológico Argentino, Buenos Aires, Actas, vol. 2, pp. 311-325.

Ramos, V.A., 1999. Las provincias geológicas del territorio argentino. In: Caminos, R. (Ed. ), Geología Argentina. Instituto de Geología y Recursos Minerales, Anales 29 (3), Buenos Aires, Argentina, pp. 41-96.

Ramos, V.A., 2008. Patagonia: a Paleozoic continent adrift? J. S. Am. Earth Sci. 26, 235-251.

Ramos, V.A., Kostadinoff, J., 2005. La cuenca de Claromecó. In: de Barrio, R.E., Etcheverry, R.O., Caballé, M.F., Llambías, E. (Eds.), Geología y Recursos Minerales de la Provincia de Buenos Aires. Relatorio del $16^{\circ}$ Congreso Geológico Argentino, Buenos Aires, Argentina, pp. 473-480.

Ramos, V., Jordan, T., Allmendinger, R., Kay, S., Cortés, J., Palma, M., 1984. Chilenia: un terreno alóctono en la evolución paleozoica de los Andes Centrales. In: $9^{\circ}$ Congreso Geológico Argentino, Buenos Aires, Actas, vol. 1, pp. 84-106.

Ramos, V.A., Chemale Jr., F., Naipauer, M., Pazos, P.J., 2014. A provenance study of the Paleozoic Ventania System (Argentina): transient complex sources from Western and Eastern Gondwana. Gondwana Res. 26, 719-740.

Rapela, C.W., Pankhurst, R.J., Fanning, C.M., Grecco, L.E., 2003. Basement evolution of the Sierra de la Ventana Fold Belt: new evidence for Cambrian continental rifting along the southern margin of Gondwana. J. Geol. Soc. 160, 613-628.

Rapela, C., Pankhurst, R., Casquet, C., Fanning, C., Baldo, E., González-Casado, J., Galindo, C., Dahlquist, J., 2007. The Río de la Plata craton and the assembly of SW Gondwana. Earth-Sci. Rev. 83, 49-82.

Rice, J.M., 1980. Phase equilibria involving humite minerals in impure dolomitic limestones. Part II. calculated stability of chondrodite and norbergite. Contrib. Miner. Petrol. 75, 205-223.

Rollinson, H., 1993. Using Geochemical Data: Evaluation, Presentation, Interpretation. Longman Scientific \& Technical, Harlow.

Rossello, E.A., Massabie, A.C., López-Gamundí, O.R., Cobbold, P.R., Gapais, D., 1997. Late Paleozoic transpression in Buenos Aires and northeast Patagonia ranges, Argentina. J. S. Am. Earth Sci. 10, 389-402.

Sato, K., Tassinari, C.C.G., Kawashita, K., Petronilho, L., 1995. O método geocronológico Sm-Nd no IG/USP e suas aplicações. An. Acad. Bras. Cienc. 67, 313-336.

Sato, K., Basei, M.A.S., Ferreira, C.M., Vlach, S.R.F., Ivanuch, W., Siga Jr., O., Onoe, A.T., 2010. In situ U-Th isotopic analyses by excimer laser ablation/ICP-MS on Brazilian megacrystal xenotime: first results of U-Pb isotopes at CPGeo-IG-USP. In: $7^{\circ}$ South American Symposium on Isotope Geology, Brasília, CD-ROM, pp. 349-352.
Schiller, W., 1930. Investigaciones geológicas en las montañas del sudoeste de la provincia de Buenos Aires. Anales del Museo de La Plata Tomo 4, 2-101.

Sellés-Martínez, J., 2001. Geología de la Ventania (Provincia de Buenos Aires (Argentina). J. Iberian Geol. 27, 43-69.

Sharp, Z.D., 1990. A laser-based microanalytical method for in situ determination of oxygen isotope ratios of silicates and oxides. Geochim. Cosmochim. Acta 54, $1353-1357$.

Sun, S.-S., McDonough, W.F., 1989. Chemical and isotopic systematics of oceanic basalts: implications for mantle composition and processes. In: Saunders, A.D., Norry, M.J. (Eds.), Magmatism in the Ocean Basins. Geological Society Special Publications 42, London, pp. 313-345.

Taylor, S.R., McLennan, S.M., 1985. The Continental Crust: Its Composition and Evolution. Blackwell Scientific Publications, Oxford.

Taylor, S.R., McLennan, S.M., 1995. The geochemical evolution of the continental crust. Rev. Geophys. 33, 241-265.

Tohver, E., Cawood, P.A., Rossello, E.A., Jourdan, F., 2012. Closure of the Clymene Ocean and formation of West Gondwana in the Cambrian: evidence from the Sierras Australes of the southernmost Rio de la Plata craton, Argentina. Gondwana Res. 21, 394-405.

Tomezzoli, R.N., 1999. La Formación Tunas en las Sierras Australes de la Provincia de Buenos Aires. Relación entre sedimentación y deformación a través de su estudio paleomagnético. Rev. Asoc. Geol. Argent. 54, 220-228.

Tomezzoli, R.N., 2001. Further palaeomagnetic results from the Sierras Australes fold and thrust belt, Argentina. Geophys. J. Int. 147, 356-366.

Tomezzoli, R.N., 2012. Chilenia y Patagonia: ¿un mismo continente a la deriva? Rev. Asoc. Geol. Argent. 69, 222-239.

Tomezzoli, R.N., Cristallini, E.O., 1998. Nuevas evidencias sobre la importancia del fallamiento en la estructura de las Sierras Australes de la Provincia de Buenos Aires. Rev. Asoc. Geol. Argent. 53, 117-129.

Tomezzoli, R.N., Cristallini, E.O., 2004. Secciones estructurales de las Sierras Australes de la provincia de Buenos Aires: Repetición de la secuencia estratigráfica a partir de fallas inversas? Rev. Asoc. Geol. Argent. 59, 330-340.

Tomezzoli, R.N., Vilas, J.F., 1999. Paleomagnetic constraints on age of deformation of the Sierras Australes thrust and fold belt, Argentina. Geophys. J. Int. 138, 857-870.

Turner, J.C., Méndez, V., 1975. Geología del sector oriental de los departamentos de Santa Victoria e Iruyá, provincia de Salta, Argentina. Bol. Acad. Nac. Cienc. (Córdoba) 51, 11-24.

Uriz, N.J., Cingolani, C.A., Chemale Jr., F., Macambira, M.B., Armstrong, R., 2011. Isotopic studies on detrital zircons of Silurian-Devonian siliciclastic sequences from Argentinean North Patagonia and Sierra de la Ventana regions: comparative provenance. Int. J. Earth Sci. 100, 571-589.

Vance, D., O’Nions, R.K., 1990. Isotopic chronometry of zoned garnets: growth kinetics and metamorphic histories. Earth Planet. Sci. Lett. 97, 227-240.

Varela, R., Cingolani, C.A., 1976. Nuevas edades radimétricas del basamento aflorante en el Perfil del Cerro Pan de Azúcar-Cerro del Corral y consideraciones sobre la evolución geocronológica de las rocas ígneas de las Sierras Australes, Provincia de Buenos Aires. In: $6^{\circ}$ Congreso Geológico Argentino, Buenos Aires, Actas, vol. 1, pp. 543-556.

Varela, R., Dalla Salda, L.H., Cingolani, C.A., 1985. Estructura y composición geológica de las sierras Colorada, Chasicó y Cortapie, Sierras Australes de Buenos Aires. Rev. Asoc. Geol. Argent. 40, 254-261.

Varela, R., Leone, E.M., Manceda, R., 1986. Estructura tectónica en la zona del cerro del Corral, Sierras Australes de Buenos Aires. Rev. Asoc. Geol. Argent. 41, 256-261.

Varela, R., Cingolani, C., Dalla Salda, L.H., 1990. Edad del granito Cerro Colorado y su implicancia geotectónica. Sierras Australes de Buenos Aires. In: $11^{\circ}$ Congreso Geológico Argentino, Buenos Aires, Actas, vol. 2, pp. 279-282.

Varela, R., Valencio, S., Ramos, A., Sato, K., González, P., Panarello, H., Roverano, D., 2001. Isotopic strontium, carbon and oxygen study on Neoproterozoic marbles from Sierra de Umango, and their foreland, Argentina. In: $3^{\circ}$ South American Symposium on Isotope Geology, Santiago de Chile, Extended abstracts, pp. 450-453.

von Gosen, W., Buggisch, W., Dimieri, L.V., 1990. Structural and metamorphic evolution of the Sierras Australes (Buenos Aires Province/Argentina). Geol. Rundsch. 79, 797-821.

von Gosen, W., Buggisch, W., Krumm, S., 1991. Metamorphism and deformation mechanisms in the Sierras Australes fold and thrust belt (Buenos Aires Province, Argentina). Tectonophysics 185, 335-356.

Whalen, J.B., Currie, K.L., Chappell, B.W., 1987. A-type granites: geochemical characteristics, discrimination and petrogénesis. Contrib. Miner. Petrol. 95, 407-419.

Woolley, A.R., Kempe, D.R.C., 1989. Carbonatites: nomenclature, average chemical compositions, and element distribution. In: Bell, K. (Ed.), Carbonatites: Genesis and Evolution. Unwin Hyman, London, pp. 1-14.

Yrigoyen, M.R., 1975. Geología del subsuelo y plataforma continental. In: $6^{\circ}$ Congreso Geológico Argentino, Buenos Aires, Relatorio, pp. 139-168.

Zharikov, V., Pertsev, N., Rusinov, V., Callegari, E., Fettes, D., 2011. Metasomatism and metasomatic rocks. In: Fettes, D., Desmons, J. (Eds.), Metamorphic Rocks: A Classification and Glossary of Terms. Recommendations of the International Union of Geological Sciences Subcommission on the Systematics of Metamorphic Rocks, New York, pp. 58-68.

Zheng, Y.-F., 1991. Calculation of oxygen isotope fractionation in metal oxides. Geochim. Cosmochim. Acta 55, 2299-2307.

Zheng, Y.-F., 1993a. Calculation of oxygen isotope fractionation in anhydrous silicate minerals. Geochim. Cosmochim. Acta 57, 1079-1091.

Zheng, Y.-F., 1993b. Calculation of oxygen isotope fractionation in hydroxyl-bearing silicates. Earth Planet. Sci. Lett. 120, 247-263. 